NBER WORKING PAPER SERIES

\title{
THE STRUGGLE FOR PALESTINIAN HEARTS AND MINDS: VIOLENCE AND PUBLIC OPINION IN THE SECOND INTIFADA
}

\author{
David A. Jaeger \\ Esteban F. Klor \\ Sami H. Miaari \\ M. Daniele Paserman \\ Working Paper 13956 \\ http://www.nber.org/papers/w13956 \\ NATIONAL BUREAU OF ECONOMIC RESEARCH \\ 1050 Massachusetts Avenue \\ Cambridge, MA 02138 \\ April 2008
}

e are deeply grateful to the Jerusalem Media and Communication Center and the Development Studies Programme at Bir Zeit University for kindly providing us with their micro data. The authors thank Jesse Shapiro, Ivàn Fernàndez-Val and seminar participants at the Samuel Neaman Institute, IZA, the NBER Summer Institute, the Conference on Conflict and Cooperation at Northwestern University, The Hebrew University, Boston University, the City University of New York Graduate Center, and Ben Gurion University for comments. David Jaeger and Daniele Paserman thank the Samuel Neaman Institute for financial support. The views expressed herein are those of the author(s) and do not necessarily reflect the views of the National Bureau of Economic Research.

NBER working papers are circulated for discussion and comment purposes. They have not been peerreviewed or been subject to the review by the NBER Board of Directors that accompanies official NBER publications.

(C) 2008 by David A. Jaeger, Esteban F. Klor, Sami H. Miaari, and M. Daniele Paserman. All rights reserved. Short sections of text, not to exceed two paragraphs, may be quoted without explicit permission provided that full credit, including $(\odot$ notice, is given to the source. 
The Struggle for Palestinian Hearts and Minds: Violence and Public Opinion in the Second Intifada

David A. Jaeger, Esteban F. Klor, Sami H. Miaari, and M. Daniele Paserman

NBER Working Paper No. 13956

April 2008

JEL No. D72,D74,D86,D89,H56,H71

\begin{abstract}
$\underline{\text { ABSTRACT }}$
This paper examines how violence in the Second Intifada influences Palestinian public opinion. Using micro data from a series of opinion polls linked to data on fatalities, we find that Israeli violence against Palestinians leads them to support more radical factions and more radical attitudes towards the conflict. This effect is temporary, however, and vanishes completely within 90 days. We also find some evidence that Palestinian fatalities lead to the polarization of the population and to increased disaffection and a lack of support for any faction. Geographically proximate Palestinian fatalities have a larger effect than those that are distant, while Palestinian fatalities in targeted killings have a smaller effect relative to other fatalities. Although overall Israeli fatalities do not seem to affect Palestinian public opinion, when we divide those fatalities by the different factions claiming responsibility for them, we find some evidence that increased Israeli fatalities are effective in increasing support for the faction that claimed them.
\end{abstract}

David A. Jaeger

College of William and Mary

Department of Economics

P.O. Box 8795

Williamsburg, VA 23187-8795

djaeger@wm.edu

Esteban F. Klor

Dept. of Economics

Hebrew University

Mount Scopus

Jerusalem ISRAEL 91905

eklor@mscc.huji.ac.il
Sami H. Miaari

Dept. of Economics

Hebrew University

Mount Scopus

Jerusalem ISRAEL 91905

smiaari@gmail.com

M. Daniele Paserman

Department of Economics

Boston University

270 Bay State Road

Boston, MA 02215

and NBER

paserman@bu.edu 
More than conventional warfare that pits two large armies of roughly equal strength against each other on a battlefield, modern conflict often pits two sides of unequal strength in an effort to influence the hearts and minds of civilians on both sides. These conflicts, in which a limited number of fatalities are used to affect negotiations, demoralize the civilian population, or strategically incapacitate the opponent, are largely psychological. Public opinion plays a crucial role in such conflicts, to the point that most of the battles are conducted through the news media.

In the context of the long-standing conflict between Israel and the Palestinians, the Second Intifada has been characterized by the increased use of suicide bombings by the Palestinians, and targeted killings of Palestinians by Israel, both which, either by design or by chance, often result in the death of civilians who are not involved in combat nor are the targets of the attack. These direct and extremely violent actions by both sides are intended, at least in part, to create fear and to reduce the willingness to resist in the opposite side. By their very nature, they convey an important message that goes beyond the actual damage or incapacitation that they might cause to the other side. For example, attacks and collective punishment such as curfews or border closings and movement restrictions imposed by the Israeli government might be aimed at convincing the Palestinians that Israel is not going to "surrender to violence." Such messages, however, may be intended not only for the opposing violent factions, but also for the general public on both sides. Attacks by Palestinian organizations might be intended to demonstrate to the Palestinian public the resolve of those organizations to continue the struggle against the occupation by any means and at any cost.

There are, of course, dissenting views regarding the effects of Israeli and Palestinian fatalities on the preferences of the Palestinian people. On the one hand, several scholars and political commentators claim that counter-terrorism in general, and targeted killings in particular, 
have a "boomerang" effect. Accordingly, these harsh measures foster hatred and desire for revenge among the Palestinian population. Counter-terrorism, therefore, directly causes the radicalization and mobilization of the Palestinians, encouraging yet more attacks against Israelis (Rubinstein, 2002; Rosendorff and Sandler, 2004; Kaplan et al., 2005; Siquiera and Sandler, 2006). ${ }^{1}$ In the words of Marwan Barghouti, former head of the Tanzim (an armed faction affiliated with Fatah):

First of all $[\ldots]$ the assassination policy is a policy of terror. It's also a very dangerous moral issue. And it also doesn't solve anything. Really. It just raises the level of hatred between the two peoples. ${ }^{2}$

On the other hand, the opposing view holds that Israel uses active measures of counterterrorism because they are an effective tool in disrupting the operations of the Palestinian military organizations (Brophy-Baermann and Conybeare, 1994; Ganor, 2005). Zussman and Zussman (2006) report that the Israeli stock market reacts positively to the assassination of senior Palestinian military leaders, reflecting the expectation that future levels of terrorism will decrease. Similarly, Jaeger and Paserman (2007) find that targeted killings have a short-term deterrent or incapacitation effect: the overall number of Israeli fatalities and the number of Israelis killed in suicide attacks fall in the first week after a targeted killing.

According to this view, a pro-active policy that includes curfews, closures and targeted killings incapacitates Palestinian military organizations. Perhaps more importantly, these measures are meant to punish and cause fear among the wider Palestinian population and deter

\footnotetext{
${ }^{1}$ Terrorism and counter-terrorism are contested terms, as a given act can be defined in opposite ways by the two sides to the conflict. Whereas Palestinians view their struggle in terms of resistance against the Israeli occupation, Israelis view this resistance as terrorism. We will subsequently refer to the outcomes of such actions using only the general terms of Palestinian and Israeli fatalities.

2 “Death Isn't a Big Deal Anymore,” Ha'aretz, 12 November 2001.
} 
regular citizens from committing attacks and supporting military organizations. For example, Moshe Ya'alon, former chief of staff of the Israeli Defense Forces (IDF) has said:

I defined [victory] from the beginning of the confrontation: the very deep internalization by the Palestinians that terrorism and violence will not defeat us, will not make us fold. If that deep internalization does not exist at the end of the confrontation, we will have a strategic problem with an existential threat to Israel. If that [lesson] is not burned into the Palestinian and Arab consciousness, [emphasis ours] there will be no end to their demands of us. Despite our military might, the region will perceive us as being even weaker. ${ }^{3}$

Ya'alon defines victory in the Intifada not only as a military defeat, but mostly in terms of the mindset of the Palestinians. In this view, continued Israeli violence should lead to a reduction in the support for continuing violence against Israelis. ${ }^{4}$

This paper empirically examines the effects of Palestinian and Israeli fatalities on the preferences of the Palestinian population. We combine daily data on fatalities from the beginning of the Second Intifada in September 2000 to February 2007 with micro data measuring the preferences of the Palestinian population. The data on preferences were obtained from a set of opinion surveys conducted during the same time period and comprise a large representative sample of Palestinians. We use the temporal and spatial variation in fatalities and the population's preferences to empirically test the two competing theories regarding the effects of violent attacks mentioned above.

Our empirical results support the hypothesis that Palestinian fatalities lead the Palestinian population to move away from more moderate positions. Within one month of their occurrence,

\footnotetext{
3 “The Enemy Within,” Ha'aretz, 30 August 2002.

${ }^{4}$ A thorough theoretical analysis by Bueno de Mesquita and Dickson (2007) establishes conditions for whether counter-terrorism brings about the radicalization or moderation of the targeted population. Accordingly, counterterrorism brings about the radicalization of the population when it causes significant economic damage and suffering not only on the terrorists but on the whole population.
} 
Palestinian fatalities shift political support away from the moderate Fatah faction, and lower support for negotiations with Israel. This movement away from moderate positions of the population, however, steadily dissipates over time and totally disappears after ninety days. Interestingly, an increase in Palestinian fatalities does not shift preferences in support of Hamas (the largest and most important radical faction) or other radical factions. Rather, it seems to lead to disaffection of the Palestinian population from the existing political factions. We also find that geographically proximate Palestinian fatalities have a larger effect than those that are distant. Palestinian fatalities in targeted killings, on the other hand, have a smaller effect on the population's preferences relative to other fatalities. Lastly, we find evidence that the shift away from moderate positions is larger for Palestinians who were expected a priori to be more radical.

These results are consistent with the conclusions of other studies focusing on the IsraeliPalestinian conflict. As in Berrebi and Klor (2006), we find that violent attacks have a significant effect on the preferences of the aggrieved population. In addition, the local effect of fatalities on the preferences of the Palestinian population is similar in nature to the increase in the electoral support for more radical Israeli political parties as a consequence of local Israeli fatalities (Berrebi and Klor, 2007).

Finally, we exploit our rich data set to test the hypothesis that Palestinian factions use violence not only as a means through which to fight the occupation, but also as an attempt to establish their radical credentials and influence the preferences of the Palestinian population (Bloom, 2004 and 2005). ${ }^{5}$ The implicit assumption on which this theory rests is that successful attacks against Israeli targets raises support for the faction responsible. We therefore examine whether the number of Israeli fatalities claimed by each faction affects support for those factions.

\footnotetext{
${ }^{5}$ Kydd and Walter (2006) analyze the outbidding strategy along with other strategies used by these organizations.
} 
This hypothesis is partially supported by the data. We find evidence of outbidding behavior between Hamas and Palestinian Islamic Jihad (PIJ), two competing radical factions. When Hamas claims responsibility for Israeli fatalities, public support for it decreases while support for the PIJ decreases. Similarly, when the PIJ claims Israeli fatalities, public support for Hamas decreases. On the other hand, we find no evidence that Israeli fatalities claimed by Hamas affect the relative support for Fatah, nor vice versa.

\section{Data}

\section{A. Palestinian Public Opinion Data}

The data on Palestinian public opinion comes from a set of surveys conducted by the Development Studies Programme (DSP) at Bir Zeit University. This institute has conducted regular public opinion polls on all aspects of Palestinian life since the year 2000. Every poll has 1,200 observations, with approximately $65 \%$ of them from the West Bank and Jerusalem and the rest from the Gaza Strip. General information on these polls, including methodology, the wording of the questions, and summary results are available from the DSP web site. ${ }^{6}$

The DSP polls contain information on the gender, age, marital status, education level, refugee status, type of residence (city, village or refugee camp) and, notably, the district of residence of each respondent. This information is very important for our purposes, since it allows us to estimate the effect of fatalities on public opinion using a high level of spatial variation. In addition, the polls include a wide array of questions on economic conditions, perceptions of

\footnotetext{
${ }^{6}$ The participants for each poll are randomly chosen using sampling techniques in sample selection applied to statistical cells built using The Housing and Economic Establishment Census conducted by the Palestinian Central Bureau of Statistics. The selection of the area, the drawing of the map, the selection of the starting point and the gender of the respondent in the sample are according to a Kish Grid. Further information can be found at the institute's official website (http://home.birzeit.edu/dsp/opinionpolls, last seen on 25 February 2008).
} 
corruption, democracy, human rights, and various other social issues. Only a limited number of questions, however, appear repeatedly across polls. We employ the two questions that appear consistently and that inform us about respondents' political preferences: "Which of the following political groups do you support?" and “Do you support or oppose the continuation of negotiations with the Israelis?” Table 1 presents the dates of the polls conducted since the outburst of the Second Intifada and indicates which questions were asked in each poll.

Political faction supported. The available options included all the major Palestinian factions. ${ }^{7}$ In addition, respondents who stated that they were independent were asked whether their preferences leaned towards Fatah, to one of the Islamic factions, or to one of the leftist factions. ${ }^{8}$ The question on political support appeared in 17 polls between November 2000 and February 2007, for a total of 19,904 observations. Fatah received 29.6 percent support on average over the whole period, while Hamas received 22.1 percent. Notably, the proportion of respondents reporting that they do not support any group was 28.6 percent, nearly as large as the proportion supporting Fatah. This suggests that a large fraction of the Palestinian population

\footnotetext{
${ }^{7}$ The two main Palestinian political factions are Fatah and Hamas. Fatah was founded by Yasir Arafat in 1959, and from 1969 it has been the controlling group of the Palestinian national movement, first in the Palestinian Liberation Organization, and subsequently in the Palestinian National Authority, after it was established in 1993 following the Oslo Peace Accords. As the majority party, Fatah has been the primary negotiator with the Israeli government. It has adopted the two-state approach to the solution of the conflict, agreeing in principle to a partition of mandatory Palestine between a Jewish and a Palestinian state, although the issues of Jerusalem, the final borders of the Palestinian state, and the status of refugees have been postponed to final status negotiations. Unlike Fatah, Hamas does not entertain the possibility of a two-state solution. Hamas has expressly called for the destruction of Israel and the establishment of an Islamist state in all of mandatory Palestine (Mishal and Sela, 2000). Hamas has also been able to establish a strong support base through its provision of social services (Berman and Laitin, 2008).

${ }^{8}$ The two main leftist factions are the Popular Front for the liberation of Palestine (PFLP) and the Democratic Front for the Liberation of Palestine (DFLP). We coded independents leaning to Fatah together with outright Fatah supporters.
} 
feels disaffection from the Palestinian political parties. We address this issue in our empirical analysis and characterize the attitudes of this group. ${ }^{9}$

Support for peace negotiations. In twelve polls, between November 2000 and September 2006, respondents were asked whether they supported or opposed the continuation of peace talks with Israel, giving a total of 13,692 observations on this variable. Over the whole period of interest, an average of 59.6 percent of Palestinians supported negotiations with Israel, 36.9 percent opposed negotiations, while the remainder did not know or did not answer. We characterize support of negotiations as being a more moderate position than being opposed to negotiations.

In Table 2 we characterize supporters of the different factions in terms of their level of radicalization. To this end, the first row of this table shows the percentage of individuals that support peace negotiations among the supporters of the different factions from the DSP data discussed above. Among supporters of Fatah, we find that 72 percent support peace negotiations, while only 48 percent of Hamas supporters do; clearly, Fatah supporters exhibit a more moderate position than Hamas supporters regarding peace negotiations. Moreover, we observe that individuals dissatisfied with the existing factions exhibit on average a more radical position than Fatah supporters, but a more moderate position than Hamas supporters.

As corroborative evidence, in rows 2 to 5 we present results from a series of public opinion polls conducted by a different polling institute, the Jerusalem Media and Communication Center (JMCC). In these polls, Palestinians were asked which of the political factions they

\footnotetext{
${ }^{9}$ The other factions that received a significant amount of support are the Palestinian Islamic Jihad (9.46 percent when grouped with other Islamic factions) and the Popular Front for the Liberation of Palestine (2.75 percent).
} 
"trusted most" in addition to a broader series of questions on attitudes towards the conflict. ${ }^{10}$ In each of the rows, the questions are coded to indicate the more moderate position. In each case, we find strong evidence that Fatah supporters are more likely to hold a moderate position than those who support Hamas or the other factions. In addition, dissatisfied individuals are consistently more moderate than Hamas supporters but more radical than those in favor of Fatah.

Figure 1 exhibits the evolution of the Palestinian population's preferences as measured by the questions discussed above. The average support for Fatah falls from an initial level of about 30 percent at the end of the year 2000 to about 20 percent after the first year of the Intifada, then rises back slowly to its initial level between 2002 and 2004, jumps abruptly in late 2004 after the death of Yasser Arafat, and then steadily declines. The fraction of Palestinians supporting negotiations with Israel presents a more erratic trend, even though qualitatively the pattern of peaks and troughs roughly matches the one observed for the Fatah support series.

\section{B. Data on Fatalities}

The data on fatalities are the same as those used in Jaeger and Paserman (2006, 2007, and 2008). The data are taken from the web site of B'Tselem, an Israeli human rights organization. ${ }^{11}$ Widely thought to be accurate and reliable, the data published by B'Tselem record in detail every fatality (excluding suicide bombers) on both sides of the conflict during the Second Intifada. They include information on the date, location and circumstances of the fatal wounding, the date

\footnotetext{
${ }^{10}$ The JMCC has conducted polls on Palestinian political opinions since 1993, though the data in Table 2 focus exclusively on those polls conducted since the outbreak of the second Intifada in September 2000. One of the main advantages of the JMCC opinion polls is that in addition to faction supported, there are four questions related to the conflict that are asked consistently over time. Unfortunately, we are not able to use the JMCC polls in our econometric analysis because they do not identify the district of residence of the respondent. General information on these polls, including methodology, the exact wording of the questions, and summary results are available from the JMCC website (http://www.jmcc.org, last seen 25 February 2008).

${ }^{11}$ The B'Tselem website is http://www.btselem.org, last seen 25 February 2008.
} 
of death, the age, gender and locality of residence of the victim, and whether the victim was a civilian or a member of the security forces. The main advantage of these data is their comprehensiveness and the symmetrical treatment of fatalities on both sides of the conflict, something that is unavailable in the official statistics compiled by either side.

We classify each Palestinian fatality according to the district where the fatal wounding took place, and whether or not he or she died during a targeted killing operation. We perform a similar classification of Israeli fatalities according to the district where the attack originated. Finally, we calculate the number of Israeli fatalities claimed by the different Palestinian factions (again, separately for each district), using the database on incidents and casualties in the Second Intifada prepared by the Institute for Counter Terrorism (ICT) at the Interdisciplinary Center in Herzliya, Israel, cross-validated with newspaper reports.

In Table 3, we present the geographic variation in the average number of fatalities. For Palestinian fatalities and for Israeli fatalities occurring in the occupied territories, we simply record the district where the fatal wounding occurred; for Israeli fatalities in Israel, we record the Palestinian district from which the attack originated. The table also highlights Palestinian fatalities killed in targeted killings, and it differentiates Israeli fatalities according to the group claiming responsibility for the particular attack. An average district suffered slightly over 9.3 Palestinian fatalities and claimed almost 2.4 Israeli fatalities.

The table depicts the high variability across districts in the number of fatalities that occur ninety days before each poll. There are a number of very violent districts in the West Bank like Jenin, Nablus and Hebron with a high number of Palestinian and claimed Israeli fatalities, whereas other districts exhibit a total number of fatalities well below the average. The variability across districts in the West Bank highlights the importance of exploiting both time series and 
cross sectional variability in our analysis. For example, if the Palestinian population is sorted across districts according to their political preferences and violence occurs mainly in radical districts, a simple cross-sectional analysis would yield a spurious correlation between radical attitudes and violence, while the actual direction of causality runs from attitudes to violence, and not the other way round. The availability of longitudinal data allows us to include district fixed effects in the analysis, so that we can separate the effect of violence from attributes of the district that are constant across time.

In contrast to the West Bank and Jerusalem, the average number of Palestinian fatalities of every district in Gaza is above the average, while the average number of Israeli fatalities originating in these districts is below the overall average. Particularly noteworthy is the number of fatalities in Gaza City, showing an average of almost 23 Palestinian fatalities within ninety days before each poll (with almost 8 of them as a result of targeted killings) and only 1.48 Israeli fatalities originating there. This gap between Palestinian and claimed Israeli fatalities in Gaza is perhaps due to the fact that border closures in the Gaza Strip are easier to implement, thus keeping its residents away from Israeli territory.

The monthly number of Palestinian and Israeli fatalities during our sample period is shown in Figure 2. The figure shows that initially Palestinian fatalities outnumbered Israeli fatalities by a large amount, and then both series rose until Operation Defensive Shield (ODS) in March 2002. After ODS, the overall trend in Israeli fatalities sloped downward, while the number of Palestinian fatalities remained at a high level until the beginning of 2005. During 2005 and parts of 2006 we observe an important drop in the level of Palestinian fatalities. This was followed by a sharp increase in the summer of 2006 as a consequence of military operations conducted by 
Israel in Gaza following the abduction of an Israeli soldier and coincident with the Second Lebanon War.

These trends, combined with those in Figure 1, suggest that Palestinian public opinion may be more radical when Palestinian fatalities outnumber Israeli fatalities by a large amount (for example, in 2002-2003), and moderate when the difference is relatively small (e.g., 2005). An alternative interpretation is that the decline in the number of Israeli fatalities coupled with the stable number of Palestinian fatalities after 2002 induce the Palestinians to take on more moderate positions. These observations are based only on visually inspecting the data, however, and ignore important events, like Yasser Arafat's death, that might have affected both trends. In the next section we propose an empirical framework to investigate the effect of violence on Palestinian preferences, using regression analysis to exploit both geographic and time variation in public opinion and in the level of fatalities.

\section{Empirical Framework}

Our empirical specification allows us to examine how violence on both sides of the conflict affects the radicalization of the Palestinian population, as measured by the DSP questions. Our general specification for the relationship between public opinion and violence is:

$$
\begin{aligned}
Y_{i j t}=a_{1} P_{j, t-1}+a_{2} P_{j, t-2}+\ldots+a_{12} P_{j, t-12}+ \\
b_{1} I_{j, t-1}+b_{2} I_{j, t-2}+\ldots+b_{12} I_{j, t-12}+\mathbf{X}_{i j t} \Phi+\mathbf{Z}_{t} \delta+c_{j}+u_{i j t} .
\end{aligned}
$$

where $Y_{i j t}$ is a binary indicator for whether individual $i$ in district $j$ and poll conducted at time $t$ expresses a moderate or radical preference - our primary indicator being support for Fatah; $P_{j, t-k}$ is the number of Palestinian fatalities in district $j$ that occurred $k$ weeks prior to date $t$; $I_{j, t-k}$ is the number of Israeli fatalities that originated in district $j$ and occurred $k$ weeks before date $t$; $\mathbf{X}_{i j t}$ is a 
vector of individual and time-varying district characteristics as well as period dummies; $\mathbf{Z}_{t}$ is a vector of variables that are common to all districts at time $t ; c_{j}$ is a district fixed effect; and the $a$ 's, $b$ 's and the vector $\Phi$ are unknown parameters that need to be estimated. Non-systematic determinants of the support for a moderate position are captured by the error term, $u_{i j t}$.

This general specification allows fatalities at every different lag (in weeks) to have a potentially different effect on the support for moderate positions. ${ }^{12}$ Given our data, however, it may be impossible to estimate separately the $a$ 's and the $b$ 's with a satisfactory degree of precision. Therefore, we impose the following restrictions:

$$
a_{k}= \begin{cases}\alpha_{1} & \text { for } 1 \leq k \leq 4 \\ \alpha_{2} & \text { for } 5 \leq k \leq 8 \\ \alpha_{3} & \text { for } 9 \leq k \leq 12\end{cases}
$$

and

$$
b_{k}= \begin{cases}\beta_{1} & \text { for } 1 \leq k \leq 4 \\ \beta_{2} & \text { for } 5 \leq k \leq 8 \\ \beta_{3} & \text { for } 9 \leq k \leq 12\end{cases}
$$

Substituting (2a) and (2b) into (1), we obtain the following compact specification:

$$
\begin{aligned}
Y_{i j t}= & \alpha_{1} \sum_{k=1}^{4} P_{j, t-k}+\alpha_{2} \sum_{k=5}^{8} P_{j, t-k}+\alpha_{3} \sum_{k=9}^{12} P_{j, t-k}+ \\
& \beta_{1} \sum_{k=1}^{4} I_{j, t-k}+\beta_{2} \sum_{k=5}^{8} I_{j, t-k}+\beta_{3} \sum_{k=9}^{12} I_{j, t-k}+\mathbf{X}_{i j t} \Phi+\mathbf{Z}_{t} \delta+c_{j}+u_{i j t} .
\end{aligned}
$$

This specification imposes the restriction that the effect of fatalities is the same within each month (i.e. four-week periods) prior to the poll at time $t$ but may vary between months. Specifically, $\alpha_{l}$ represents the effect of one Palestinian fatality that occurred in the first month that preceded the poll (we call this the immediate effect) while $\alpha_{2}$ and $\alpha_{3}$ represent the effect of

\footnotetext{
${ }^{12}$ For fatalities occurring more than 12 weeks before the poll, we assume that the effect is zero.
} 
one Palestinian fatality that occurred two and three months before the poll, respectively. As shown in Table 4, by focusing on broader time intervals we are basically employing cells with a relatively large number of fatalities as well as a significant variance. Using long enough time periods to generate sufficient variation in the right hand side variables is crucial to being able to estimate the coefficients of equation (3) with a satisfactory level of precision. ${ }^{13}$

Two additional remarks about our empirical specification are in order. First, if we restrict the $\alpha_{1}, \alpha_{2}$, and $\alpha_{3}$ to be equal, we essentially constrain the effect of every Palestinian fatality in the 12 weeks preceding the poll to be constant. The same interpretation is given to $\beta_{1}, \beta_{2}$ and $\beta_{3}$ with respect to Israeli fatalities. We present results for both the constant-effect specification and for the dynamic specification, where we allow the effects of fatalities to differ over time. ${ }^{14}$

Second, in the above specification the individual coefficients tell us the effect of a onetime increase in violence, occurring exactly $k$ weeks before the poll. We may also be interested in the long-run effect of a permanent increase in the level of violence. Taking into consideration the lengths of the periods captured by each coefficient, the long-run effect of a permanent increase in Palestinian fatalities equals $4\left(\alpha_{1}+\alpha_{2}+\alpha_{3}\right)$, while the long-run effect of an increase in Israeli fatalities equals $4\left(\beta_{1}+\beta_{2}+\beta_{3}\right)$. These long-run effects will be reported alongside the individual coefficients in each table.

\footnotetext{
${ }^{13}$ The careful reader will have noted that the average number of fatalities in the weeks immediately preceding the poll appears to be lower than in previous weeks. This raises the reasonable suspicion that the timing of the polls may not be random with respect to the level of violence. This is not a major source of concern, however, since selection on the basis of an explanatory variable does not bias the regression coefficients, but may increase the estimated standard errors. Hence, this should bias against us finding significant effects of violence.

${ }^{14}$ We have experimented with different lag structures. In no case did we find statistically significant effects past the third month prior to the poll. Moreover, based on (admittedly low-power) model specification tests, for both the Akaike and Bayesian information criteria it is never the case that a model with more than 3 monthly lags is the bestfitting model. We therefore use a specification with 3 monthly lags as one that captures the relationship between public opinion and violence with a sufficient degree of parsimony. These results are available from the authors by request.
} 


\section{Results}

\section{A. Support for Palestinian factions by demographic characteristics}

We first examine how support for the Palestinian factions varies by demographic group by pooling all the DSP surveys. The first four columns of Table 5 show the share of each demographic group that supports each of the major factions (the columns sum to 100 percent within each row), while the last column shows percentage of respondents who support Fatah among those who support either Fatah or Hamas.

The results in Table 5 suggest that there are no clear and striking differences between Fatah and Hamas supporters regarding areas and types of residency, refugee status, marital status and age. Females, however, show a greater tendency to support Hamas relative to males, perhaps because of the greater degree of social services that Hamas provides. With regard to education, support for Fatah relative to Hamas does not increase monotonically, but follows a U-shape pattern. This is driven, however, by individuals with some college or more advanced education being less likely to support Hamas and more likely to support one of the smaller factions, with the support for Fatah relatively unaffected.

The bottom of Table 5 presents evidence on the relationship between local economic indicators and the political support for Fatah and Hamas. These indicators, calculated from micro data obtained from the Palestinian Labor Force Survey, measure the quarterly unemployment rate and average wage of each district. ${ }^{15}$ These figures indicate that there is no strong correlation between economic conditions and support for a given political party, even though support for

\footnotetext{
15 The survey is conducted by the Palestinian Central Bureau of Statistics. We present in the table the relaxed definition of the local unemployment rate, which includes not only workers actively looking for work but discouraged workers as well. We view this variable as more appropriate, given the very high number of discouraged workers throughout the period. Qualitatively, our results are essentially identical when we use the standard definition of unemployment.
} 
Fatah decreases in districts with high unemployment rates and low average wages. This is consistent with the economic voting hypothesis whereby voters assign the responsibility for bad economic outcomes to the governing party (Lewis-Beck and Stegmaier, 2000). ${ }^{16}$ It is also consistent with the notion that recessionary economies make mobilization for radical causes more attractive because of the lack of economic opportunity (Bueno de Mesquita, 2005; Bueno de Mesquita and Dickson, 2007). It will be, therefore, important to control for economic conditions in equation (3) to differentiate between radicalization induced by political or economic reasons. Finally, disaffection with the political system is common among all demographic groups, and is especially acute among the elderly, the illiterate, and Jerusalem residents.

\section{B. Main Results}

In Table 6 we present results from estimating equation (3) using as our dependent variable an indicator for support for Fatah (Table 6A) and an indicator for support for peace negotiations (Table 6B). The models are estimated with ordinary least squares (OLS) and the estimated heteroskedasticity-consistent standard errors allow for temporal and spatial clustering. All regressions include controls for sex, age, marital status, education, the local unemployment rate, the local wage rate and a measure of border closings. In our preferred specification (column 2) we include a full set of district dummies, and two period dummies to capture broad trends in violence and public opinion in the different phases of the conflict (before Operation Defensive Shield, between ODS and the death of Yasser Arafat, and after the death of Yasser Arafat). We

\footnotetext{
${ }^{16}$ For the overwhelming majority of our sample period, Fatah held both the presidency of the Palestinian National Authority, the majority in the Palestinian Legislative Council (PLC), and the Prime Minister's office. Hamas became the majority party in the PLC and took hold of the Prime Minister's Office following its success in the legislative elections in January 2006.
} 
assess sensitivity of our results to the exact specification of the district and time effects in the remaining columns.

In column 1 of Tables $6 \mathrm{~A}$ and $6 \mathrm{~B}$ we present estimates of the constant-effect specification, in which every Palestinian (Israeli) fatality within 12 weeks of the poll is constrained to have the same effect on the Palestinians' political preferences. Using this specification, there is no statistically significant relationship between violence and support for Fatah or peace negotiations. The dynamic-effect specification (shown in column 2) depicts a substantially different picture. When we do not constrain the coefficients to be equal, Palestinian fatalities have the immediate effect of radicalizing the population, but this effect falls off rather quickly. This result is consistent across both measures. Specifically, 10 additional Palestinian fatalities in the respondent's district of residence reduce support for Fatah in the first month after they occur by 1.5 percentage points, and they reduce the support for peace negotiations by almost 2.4 percentage points. The effect of Palestinian fatalities is not statistically significant two months after the incident, and changes sign within three months of their occurrence. Consequently, the long-run effect of a permanent increase in Palestinian fatalities on the preference for moderate attitudes, while negative, is not statistically significant.

Contrary to the effect of Palestinian fatalities, we find that Israeli fatalities claimed by individuals living in or occurring in the different districts have essentially no effect on either support for Fatah or support for negotiations with Israel. The coefficients for the first lag are negative, but estimated with little precision. This result holds in both the constant-effect and in the dynamic effects specification. 
In column 3, we present results without including district fixed effects. Consistent with our prior expectations, the coefficients on the first lag of both Palestinian and Israeli fatalities increase markedly (in absolute value), and the latter becomes statistically significant in the regression for Fatah support. This increase reflects the fact that districts with more radical attitudes are more likely to engage in violence against Israelis, and hence are also more likely to be targeted by Israeli military activity. That the coefficient on Palestinian fatalities remains statistically significant when the district fixed effects are included is reassuring, however: it suggests that most of the variation that drives the results is the over-time variation within district and not the time-invariant cross-district variation.

In columns 4 and 5, we assess the sensitivity of our results to different specifications of the time effects. In column 4, we exclude the time effects, meaning that we are using all of the variation in violence and attitudes over time for identification. The results are similar to those of column 3, i.e., both Palestinian and Israeli fatalities tend to have a larger radicalization effect. Of course, this specification attributes all of the changes over time in Palestinian attitudes to violence alone, and ignores important events that may have affected the general trend in public opinion.

At the opposite extreme, column 5 includes a full set of poll fixed effects. The poll fixed effects absorb all of the fluctuations in attitudes that are common to all Palestinians at each point in time. Hence, identification is achieved off deviations in violence and attitudes at the district level from this common time effect (and from the district-level averages). The picture now is somewhat different. The first lag of Palestinian fatalities becomes insignificant in the "support for Fatah" regression, and essentially zero in the "support for negotiations" regression. The coefficient on the first lag of Israeli fatalities increases somewhat in the "support for Fatah" 
regression relative to our preferred specification in column 2, but is not statistically significant.

On the other hand, we now find a large and significant radicalization effect of Israeli fatalities at all lags on support for negotiations. This would imply that attacks successfully carried out by Palestinian factions embolden the Palestinian population. However, we are cautious in putting too much weight on these results, since they appear to be sensitive to the choice of dependent variable, and it is not clear that it is appropriate to absorb all of the time-series variation with the poll fixed effects. ${ }^{17}$

To get a more concrete sense of the short and long run effects of Palestinian fatalities on the attitudes toward the conflict, we next run a series of 12 regressions for each dependent variable using the following specification:

$$
\begin{aligned}
Y_{i j t}= & \gamma_{m} \sum_{k=1}^{m} P_{j, t-k}+\beta_{1} \sum_{k=1}^{4} I_{j, t-k}+\beta_{2} \sum_{k=5}^{8} I_{j, t-k}+m=1, \ldots, 12 \\
& \beta_{3} \sum_{k=9}^{12} I_{j, t-k}+X_{i j t} \Phi+\mathbf{Z}_{t} \delta+c_{j}+u_{i j t},
\end{aligned}
$$

Each coefficient $\gamma_{m}$ represents the effect of all Palestinian fatalities that occurred up to $m$ weeks before the poll at time $t$. If Palestinian fatalities indeed generate a radicalization of attitudes in the short run that fades away with time, we would expect to find that the $\gamma$ s are large and negative at low values of $m$, and then revert towards zero at longer lags. Figure 3 presents the estimated $\gamma$ coefficients for Fatah support and support for peace negotiations. With the exception of the very first coefficient in the "support for peace negotiations" equation, the pattern of coefficients confirms the results from Table 6. Fatalities that occur in the first few weeks before

\footnotetext{
${ }^{17}$ It may be that Palestinian sentiment is driven more by the overall level of violence against Israelis, rather than violence originating in a specific locality. We evaluated this hypothesis by replacing the number of Israeli fatalities attributed to the district with the overall number of Israeli fatalities. The results for the effect of Israeli fatalities were imprecise, while the results for the effects of Palestinian fatalities were robust to this alternative specification. We will return to the effect of fatalities at different levels of geographic aggregation in Section IV.A.
} 
the poll induce a stronger shift toward more radical positions, but this effect is attenuated with time.

Overall, our results support the notion that Palestinian fatalities generate a short-run radicalization of the Palestinian population. This effect completely dissipates over time. In the next section we test the robustness of these results with different subpopulations and different classifications of fatalities.

\section{Extensions}

\section{A. The Effects of Geographic Variation in Preferences and Violence}

Conditions in the West Bank and East Jerusalem are substantially different than those in the Gaza Strip, and we might expect that violence has a different effect in the two areas. To test this, in Table 7 we estimate the same models estimated in our preferred specification (column 2 of Table 6), separately for the West Bank/Jerusalem and the Gaza Strip. We find very similar effects of fatalities on support for Fatah in both regions. The pattern of the effect of violence against Palestinians follows that in Table 6 - violence temporally proximate to a poll date lowers support for Fatah, but this effect quickly diminishes with the temporal distance from the poll. Border closings have a statistically significant radicalizing effect in the West Bank, but not in Gaza, perhaps due to the greater degree of variation in this variable for the West Bank. The effect of Palestinian fatalities on the support for peace negotiations of the population in the West Bank is consistent with the estimates from Table 6. The estimates using the population of the Gaza Strip, however, are not precisely estimated. Interestingly, Table 7 reveals that Israeli fatalities embolden the population of the Gaza Strip in the short run. Whereas this radicalization 
effect dissipates over time in terms of the support for Fatah, the overall effect of Israeli fatalities leads to a statistically significant decrease on the support for peace negotiations of residents of the Gaza Strip. ${ }^{18}$

Our analysis thus far has focused on Palestinian local fatalities only. That is, our fatality variables include only those Palestinian fatalities from a particular district or area and we have implicitly assumed that fatalities elsewhere have no effect on public opinion. In Table 8 we relax this assumption and, using the rich geographic detail available in the DSP data, include both local Palestinian fatalities and other Palestinian fatalities in the regressions. In columns 1 and 3 we include separately local fatalities (those that occurred in the district of residence of the respondent) and all other fatalities, again using the dynamic effect specification of equation (3). In columns 2 and 4 we separate further between local district fatalities, fatalities that occurred in other districts within the same region (West Bank or Gaza), and fatalities that occur in the other region. Strikingly, the results show that there is a clear ranking in the effects of fatalities on support for Fatah by geographic distance: fatalities that occur within the district of residence lead to the largest shift away from Fatah, followed by fatalities that occur in other districts within the same region and by fatalities that occur in the other region. For all types of fatalities, we observe a pattern consistent with the one documented in Table 6 - a radicalization of the population in the short run that dissipates over time. It appears therefore that the effect of fatalities diminishes both with temporal and geographic distance. Geographic distance, however, does not seem to affect the support for peace negotiations. The estimated coefficients on Palestinian fatalities are statistically equal for every fatality, regardless of the location of the incident.

\footnotetext{
${ }^{18}$ In related work, Iyengar and Monten (2008) also find an "emboldenment” effect of news of a U.S. withdrawal from Iraq on the actions of insurgents.
} 


\section{B. Do Targeted Killings have a Different Effect on Palestinian Preferences?}

Jaeger and Paserman (2007) have noted that targeted killings of Palestinian leaders reduce subsequent Israeli fatalities in the short run, even though they may lead to an increase in intended violence. We examine how targeted killings and other fatalities affect public opinion in Table 9. In columns 1 and 3 we differentiate between total fatalities in targeted killings (including collateral fatalities) and other fatalities, while in columns 2 and 4 we separate out the targets and other fatalities in the targeted killing. Both specifications give very similar results support for moderate attitudes is affected only by the deaths of Palestinians not in targeted killings, which follow the same pattern previously described in Table 6. Consistent with the theoretical analysis of Bueno de Mesquita and Dickson (2007), the assassination of leaders (a focused policy with low levels of negative externalities on the general population) does not lead to the radicalization of the population.

\section{Do Radicals and Moderates have a Similar Reaction to Violence?}

The previous subsections documented the effects of violence on the Palestinian population as a whole. This subsection studies the effects of violence on sub-samples of the population, grouped according to their political preferences, predicted on the basis of their timeinvariant location and demographic characteristics. This analysis allows us to establish whether or not Palestinian and Israeli fatalities cause the ideological polarization of the Palestinian population. To the best of our knowledge, there is not a clear theoretical prediction regarding the effects of violence on the ideological polarization of the population. It is nevertheless important to empirically explore this issue since the polarization of the population might be one of the main causes behind internal social and political conflicts (Sartori, 1976). In addition, even if the 
attitudes of the large majority of the population are unaffected by it, Israeli violence could still have important implications for the long-run dynamics of the conflict if enough people with a high propensity for radicalism do become more radical and are induced to join militant factions.

To study this issue, we construct a measure of radicalism for every individual in our sample, based on his or her demographic characteristics, and then test separately the effects of fatalities for more and less radical Palestinians. We adopted the following procedure: (a) we drew a $25 \%$ random sample from our population, and estimated with a probit model, separately by gender, the probability that an individual supports Fatah based only on the pooled crosssectional variables on demographic characteristics described in Table $5 ;{ }^{19}$ (b) based on these estimates, we calculated fitted probabilities of supporting Fatah for every individual in the sample; (c) we defined as "radicals" people with a fitted probability below the median predicted value, and non-radicals those with a fitted probability above this median; ${ }^{20}$ d) we estimated equation (3) on the remaining $75 \%$ of the sample (the part not used in estimating the probit models), adding the "radical" dummy, and its interaction with all lags of Palestinian and Israeli fatalities; e) we repeated steps (a)-(d) 200 times, so that our results would not be unduly affected by one particular draw of the estimation sample. In Table 10, we report the mean and the standard deviation of the parameters of interest from these 200 replications. ${ }^{21}$

We find robust evidence that Palestinian fatalities occurring 1-4 weeks before the survey lead to a polarization in public opinion: support for Fatah and for peace negotiations decreases

\footnotetext{
${ }^{19}$ The separate estimations for males and females on the full sample appear in Appendix Table 1. The results show that the unemployment rate is negatively correlated with support for Fatah for both genders. In addition, whereas support for Fatah increases among women with refugee status and among married men, it decreases among older men.

${ }^{20}$ The mean over the 200 replications of the median predicted value is 0.285 .

${ }^{21}$ The estimated effect for non-radicals is simply the coefficient on fatalities, the difference is the coefficient on the interaction between the radical dummy and fatalities, and the effect for radicals is the sum of the two.
} 
significantly among individuals with a high propensity to be radical, while those with a low propensity for radicalism are essentially unaffected. The difference in the effect is statistically significant with respect to support for Fatah, and marginally insignificant with respect to support for negotiations. As in Table 6, we find that more temporally distant Palestinian fatalities actually have a moderating effect, for both radicals and non-radicals. We also find some evidence that Israeli violence has a long-run effect on the positions of the radicals: if the monthly number of Palestinian fatalities per month were to increase by 10, support for peace negotiations would decline by 5.4 percentage points among those with a high propensity for radicalism, although this result is not statistically significantly different from zero. We find no statistically significant effects of Israeli fatalities on support for Fatah or for peace negotiations.

\section{The Effect of Violence on Support for Different Factions}

While support for Fatah (the most moderate of the factions) is an indicator of the radicalization or outrage of the Palestinian population, the surveys include more specific information regarding the factions that individuals support. Table 11 explores this issue further, by estimating a multinomial logit model for faction supported. The dependent variable takes on one of six possible values: Fatah, Hamas, PFLP, Palestinian Islamic Jihad (grouped with other Islamic groups), other factions, and no faction. To facilitate comparison with previous tables, we present the marginal effects of violence on the support for each faction, rather than the multinomial logit coefficients.

The results from this exercise confirm that increases in Palestinian fatalities shift support away from Fatah in the short run. The size of the decrease in Fatah support is comparable to that found in Table 6: 10 additional fatalities in the four weeks prior to a poll lower support for Fatah 
by roughly 1.8 percentage points. This shift is not towards more radical groups like Hamas, PLFP and PIJ, however, but rather towards more disaffection: the coefficient on "supporting no one” has roughly the same magnitude as the coefficient on support for Fatah but with opposite sign, and is only marginally insignificant ( $p$-value equal to 0.108 ). The shift away from Fatah may in fact represent radicalization as well as disaffection: the evidence in Table 2 clearly shows that individuals who support no faction have more radical preferences than Fatah supporters on all other measures. It is also possible that fatalities induce secular Palestinians to avoid expressing support for Fatah, without leading them to shift their allegiance to the Islamic or Marxist factions, whose ideology they do not share. In addition, we should not forget that all our previous results showed that Israeli violence leads to a decrease in support for negotiations with Israel, another sign of more radical preferences.

As was the case with most of our previous estimations, the shift away from Fatah dissipates over time. Local Israeli fatalities do not seem to have a significant effect in the support for any faction except for an immediate shift away from PIJ that completely dissipates over time.

\section{E. Testing the Outbidding Hypothesis}

We now test whether there is any support for the "outbidding” hypothesis, i.e., the notion that Palestinian factions use violence not only as a means through which to fight the occupation, but also as an attempt to establish their radical credentials and influence the preferences of the Palestinian population (Bloom, 2004 and 2005). The implicit assumption on which this theory rests is that successful attacks against Israeli targets raises support for the faction responsible for the attack. Therefore, we combine the public opinion data with data from the ICT recording the 
faction responsible for each Israeli fatality. The outbidding hypothesis predicts that Israeli fatalities inflicted by a given faction should raise the political support for that faction.

We examine this issue in Table 12 by estimating again a multinomial logit model, but we include separately the number of fatalities claimed by the different factions (Fatah, Hamas, PIJ, and all others). Again, the table reports the marginal effects of fatalities on support for each faction. We do not find that violence by the different factions has a large effect in changing Palestinian support for Fatah. The table provides, however, some suggestive evidence that the outbidding hypothesis applies to Hamas and Palestinian Islamic Jihad, factions that are close to each other not only in terms of their attitudes towards the conflict but also in terms of their Islamic beliefs. ${ }^{22} \mathrm{~A}$ higher number of Israeli fatalities claimed by Hamas raises the relative support for it and reduces the relative support for the PIJ. The magnitude of the effect is nonnegligible: a one-time one-standard deviation increase in Israeli fatalities claimed by Hamas (roughly 2 fatalities per district in a 4-week period) raises Hamas support by 0.8 percentage points in the first month after it occurs, with a similar permanent increase predicting an increase in support for Hamas by more than 4 percentage points. Israeli fatalities claimed by the PIJ cause an overall decrease in the support for Hamas, both in the short run and in the long run, even though they do not raise support for PIJ. We also observe that minor factions, grouped into the "others" category, are able to increase their popularity among the Palestinian public through the use of violence against Israelis.

In sum, we find some support for the key assumption underlying the outbidding hypothesis, namely that Palestinian factions can increase their popularity by carrying out attacks

\footnotetext{
${ }^{22}$ Both factions originated in Egypt as offshoots of the Muslim Brotherhood, a Sunni, Islamist, religious movement. Notably, the two factions share some of their goals, as both seek the creation of an Islamic State on the entire territory of British Mandate Palestine (Cronin et al., 2004).
} 
against Israelis. However, it appears that this strategy is effective only for shifting support between different radical factions, but not between radical factions and the moderate Fatah.

\section{Conclusions}

This paper empirically investigates the effects of violence on the attitudes of the Palestinian population using detailed micro data and rigorous statistical analysis. This is one of the central and more contentious questions regarding the Israeli-Palestinian conflict, which divides scholars and policy makers alike. Despite its importance, to the best of our knowledge there had been no study providing systematic empirical evidence on this matter, and the claims that violence increases, does not affect or decreases the radicalization of the Palestinian population were based on casual empiricism only.

We find that the average member of the Palestinian population holds more radical positions immediately after the occurrence of a Palestinian fatality in their district of residence. This effect is temporary, however, and vanishes completely within 90 days. ${ }^{23}$ The radicalization effect of Palestinian fatalities is not homogenous across individuals with ex-ante different preferences. Rather, this effect is more pronounced for individuals that are more radical a priori (based on their demographic characteristics), and it therefore brings about the polarization of the Palestinian population. Our results are robust to using different measures of public opinion as well as to the Palestinian fatalities incurred during targeted killing operations and other fatalities. We find that the magnitude of the effect is similar in Gaza and in the West Bank and Jerusalem. Interestingly, we observe that not only temporal proximity but also geographic proximity has an

\footnotetext{
${ }^{23}$ On the other side of the conflict, Zussman, Zussman, and Romanov (2007) find that violence against Israelis does not affect the level of happiness among Jewish Israelis and has only a brief (one day) negative effect on the happiness of Arab Israelis.
} 
effect on radicalization: local Palestinian fatalities have a stronger effect than Palestinian fatalities in other districts.

There are a variety of explanations for the observed local effect of fatalities on the radicalization of the population. First, violence at the local level triggers residents of a district to alter their daily routine as a consequence of a change in their perceived personal security. These threats directly affect their attitude toward the conflict and lead them to prefer more radical policies (Gordon and Arian, 2001). In addition, local violence may also affect the district's economy and its residents' expected future income, antagonizing the local population against compromises with Israel. Finally, the occurrence of local Palestinian fatalities directly affects the salience of the conflict in the affected district. Although all Palestinians are aware of the occurrence of a fatality by following information provided by the news media, Palestinians residing in the same district of the fatality may have undergone a more vivid or traumatic experience of the event. This is often reinforced by street processions before a burial and demonstrations against Israel after it.

Contrary to Palestinian fatalities, Israeli fatalities claimed by a military Palestinian organization in a given district do not seem to systematically affect the preferences of the overall Palestinian population. We do find, however, some empirical support for the outbidding hypothesis for similar factions. In particular, Israeli fatalities claimed by Hamas increase their political support and reduce the support for the Palestinian Islamic Jihad and other Islamic factions. This suggests that realized violence against Israeli targets carries some weight in the formation of Palestinian political preferences.

The Israeli-Palestinian conflict is a paradigm for many modern low-intensity conflicts. These conflicts are often protracted in time, granting more opportunities for the public to 
influence policymakers' decisions and actions. Consequently, the general population, which is directly affected by violent events, may be able to shape them to a certain extent. A better knowledge of the impact of violence on political preferences helps us to understand the evolution of modern conflicts.

To conclude, we should remark that the focus of our study is necessarily the short run. Our empirical analysis does not address the question of whether violence perpetuates the conflict by sowing the seeds of hatred among younger generations of Palestinians. What implications then can our findings have for the long-run consequences of violence? One view is that the temporary nature of the movements in Palestinian attitudes implies that outbursts of violence have little consequences for the overall level of animosity in Palestinian society, and one therefore should look elsewhere for the causes of secular shifts in public opinion. On the other hand, a sequence of such temporary shifts could have no apparent effects if taken independently, but may cumulate to create a stock of resentment, yielding fertile ground for radical sentiments to grow, and to be potentially exploited by political entrepreneurs willing to foment hatred (Glaeser, 2005). The "long run" in the Palestinian-Israel conflict would appear to still be before us. How violence affects younger generations remains an important open question in need of further research. 


\section{REFERENCES}

Berman, Eli and David D. Laitin (2008) "Religion, Terrorism and Public Goods: Testing the Club Model,” Journal of Public Economics, forthcoming.

Berrebi, Claude and Esteban F. Klor (2006) “On Terrorism and Electoral Outcomes: Theory and Evidence from the Israeli-Palestinian Conflict,” Journal of Conflict Resolution, 50(6): 899-925.

Berrebi, Claude and Esteban F. Klor (2007) “Are Voters Sensitive to Terrorism? Direct Evidence from the Israeli Electorate,” unpublished manuscript, The Hebrew University of Jerusalem.

Bloom, Mia (2004) "Palestinian Suicide Bombing: Public Support, Market Share, and Outbidding,” Political Science Quarterly 119(1): 61-88.

Bloom, Mia (2005) Dying to Kill: The Allure of Suicide Terror, New York: Columbia University Press.

Brophy-Baerman, Bryan and John A. C. Conybeare (1994) "Retaliating Against Terrorism: Rational Expectations and the Optimality of Rules versus Discretion,” American Journal of Political Science, 38(1): 196-210.

Bueno de Mesquita, Ethan (2005) “The Quality of Terror,” American Journal of Political Science, 49(3): 515-530.

Bueno de Mesquita, Ethan and Eric S. Dickson (2007) "The Propaganda of the Deed: Terrorism, Counterterrorism, and Mobilization.” American Journal of Political Science, 51(2): 364381.

Cronin, Audrey K.; Aden, Huda; Frost, Adam and Jones, Benjamin. "Foreign Terrorist Organizations.” Congressional Research Service Report RL32223, February 2004. Available online at http://www.fas.org/irp/crs/RL32223.pdf.

Ganor, Boaz (2005) The Counter-Terrorism Puzzle: A Guide for Decision Makers, New Brunswick \& London: Transaction Publishers.

Glaeser, Edward L (2005) “The Political Economy of Hatred.” Quarterly Journal of Economics, 120(1): 45-86.

Gordon, Carol and Arian, Asher. 2001. “Threat and Decision Making,” Journal of Conflict Resolution, 45(2): 196-215.

Iyengar, Radha and Jonathan Monten. 2008. "Is there an 'Emboldement' Effect? Evidence from the Insurgency in Iraq.” NBER Working Paper 13839, March 2008. 
Jaeger, David A. and M. Daniele Paserman (2006) "Israel, the Palestinians Factions, and the Cycle of Violence,” American Economic Review, 96(2): 45-49.

Jaeger, David A. and M. Daniele Paserman (2007) “The Shape of Things to Come? Assessing the Effectiveness of Suicide Attacks and Targeted Killings,” IZA Discussion Paper 2890, June.

Jaeger, David A. and M. Daniele Paserman (2008) “The Cycle of Violence? An Empirical Analysis of Fatalities in the Palestinian-Israeli Conflict," American Economic Review, forthcoming, September.

Kaplan, Edward H., Alex Mintz, Shaul Mishal, and Claudio Samban (2005) "What Happened to Suicide Bombings in Israel? Insights from a Terror Stock Model,” Studies in Conflict and Terrorism, 28(2): 225-235.

Kydd, Andrew and Barbara F. Walter (2006) “The Strategies of Terrorism,” International Security, 31(1): 49-80.

Lewis-Beck, Michael S. and Mary Stegmaier (2000). "Economic Determinants of Electoral Outcomes.” Annual Review of Political Science, 3: 183-219.

Mishal, Shaul and Avraham Sela (2006) The Palestinian Hamas: Vision, Violence, and Coexistence, New York: Columbia University Press.

Pape, Robert A. (2003) “The Strategic Logic of Suicide Terrorism,” American Political Science Review, 97(3): 1-19.

Rosendorff, Peter and Todd Sandler (2004) "Too Much of a Good Thing? The Proactive Response Dilemma,” Journal of Conflict Resolution, 48(4): 657-671.

Rubinstein, Danny (2002) “Assassinations as a Boomerang,” Ha'aretz, March 6.

Sartori, Giovanni (1976) Parties and Party Systems: A Framework for Analysis. Cambridge: Cambridge University Press.

Siqueira, Kevin, and Todd Sandler (2007) "Terrorist versus the Government: Strategic Interaction, Support, and Sponsorship, " Journal of Conflict Resolution, 50(6): 878-898.

Zussman, Asaf, and Noam Zussman (2006) “Assassinations: Evaluating the Effectiveness of an Israeli Counterterrorism Policy Using Stock Market Data” Journal of Economic Perspectives, 20(2): 193-206.

Zussman, Asaf, Noam Zussman, and Dmitri Romanov (2007) “Does Terrorism Demoralize? Evidence from Israel,” unpublished manuscript, Cornell University. 
Support for Fatah and for Peace Negotiations, 2000-2006

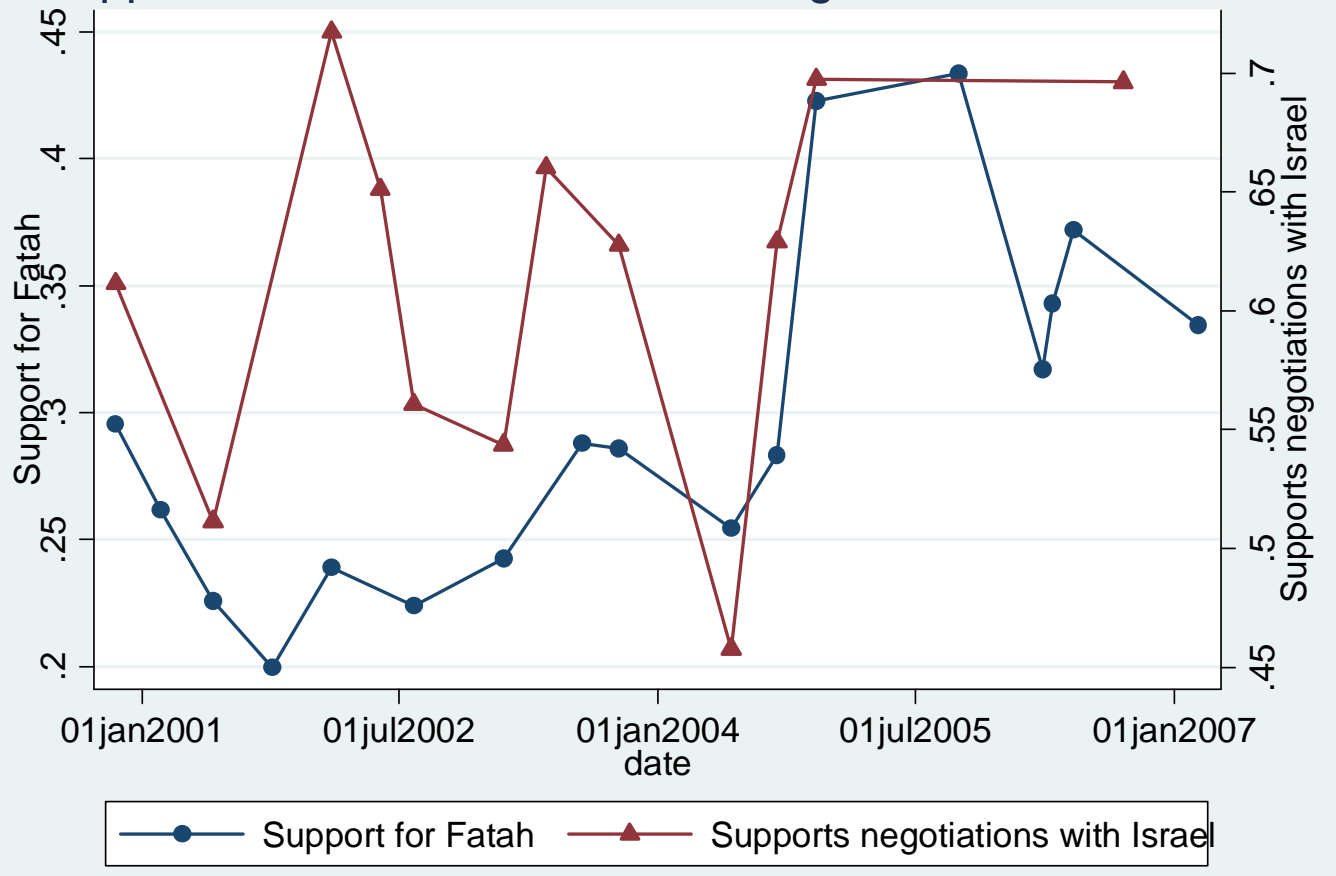

Figure 1: Support for Fatah and for Peace Negotiations 


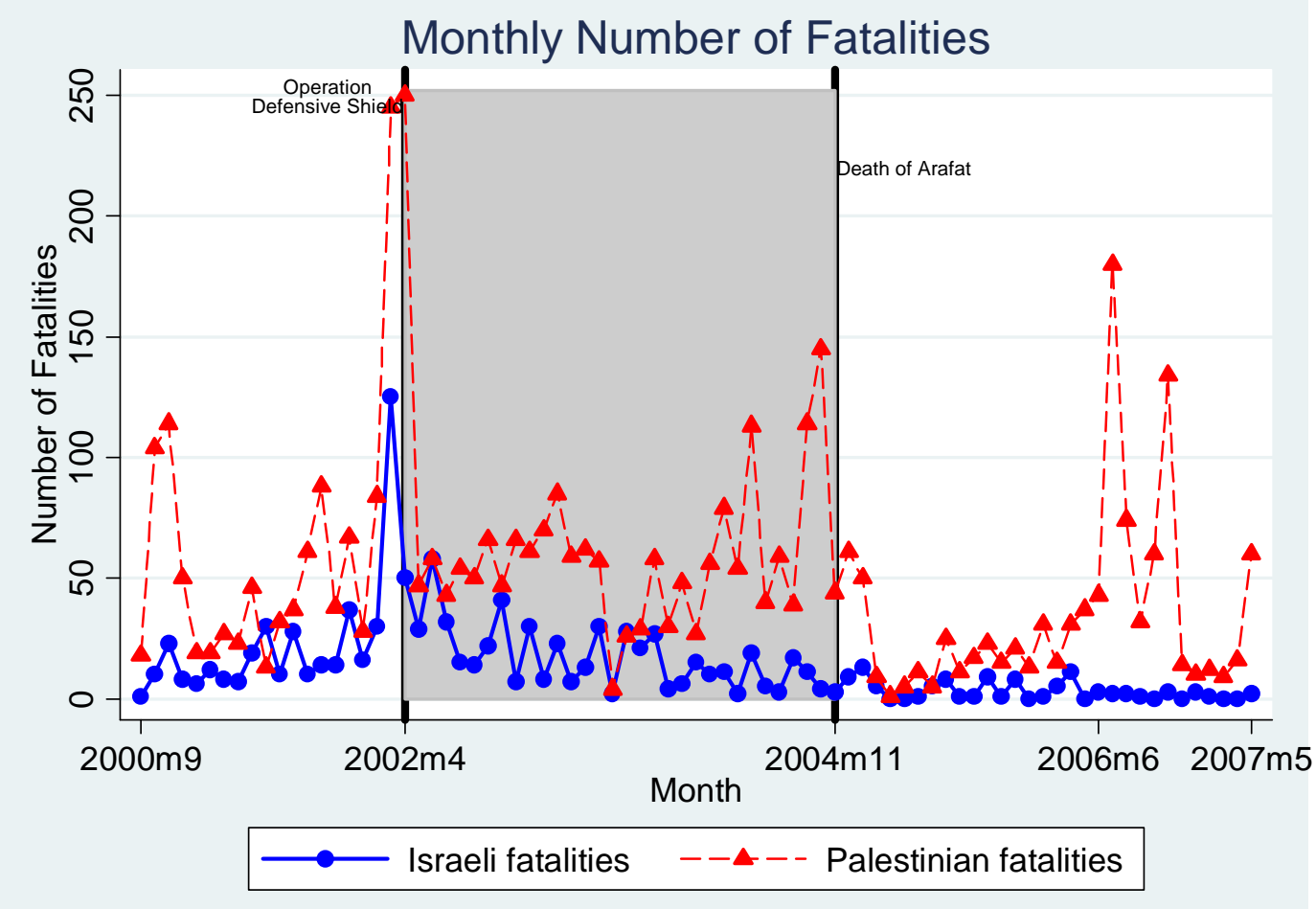

Figure 2: Monthly number of fatalities, 2000-2007 


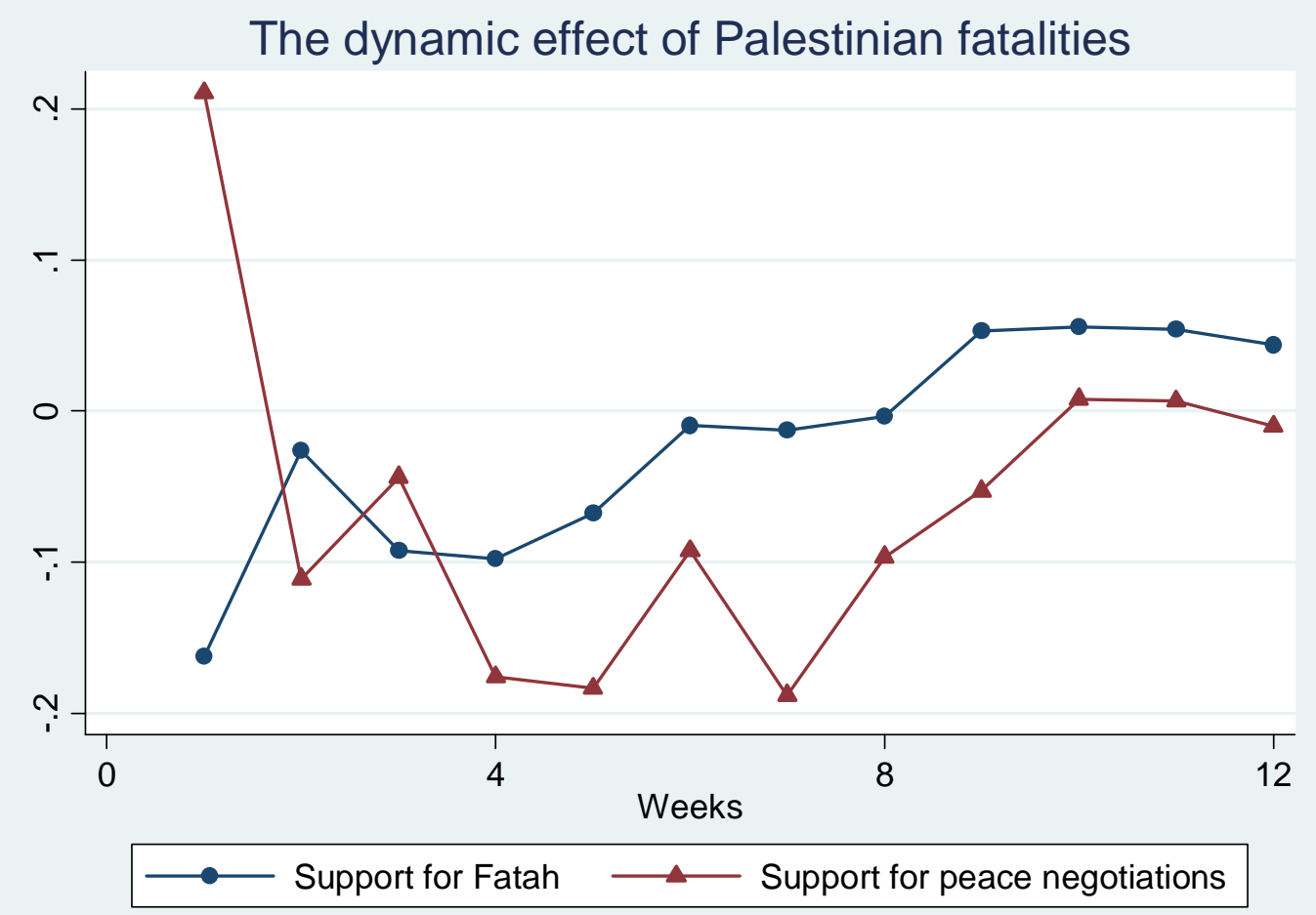

Figure 3: The dynamic effect of fatalities on Fatah support 
Table 1

Dates and Contents of DSP's Polls of Palestinian Opinion

\begin{tabular}{|c|c|c|c|c|}
\hline \multirow[b]{2}{*}{ Date } & \multirow[b]{2}{*}{ Poll \# } & \multirow[b]{2}{*}{ Period } & \multicolumn{2}{|c|}{ Exact Wording of the Questions } \\
\hline & & & $\begin{array}{l}\text { Which of the } \\
\text { following political } \\
\text { groups do you } \\
\text { support? }\end{array}$ & $\begin{array}{l}\text { Do you support or } \\
\text { oppose the } \\
\text { continuation of } \\
\text { negotiations with the } \\
\text { Israelis? }\end{array}$ \\
\hline November 6, 2000 & 2 & & $\checkmark$ & $\checkmark$ \\
\hline February 8, 2001 & 3 & Phase 1: Before & $\checkmark$ & \\
\hline May 31, 2001 & 4 & Operation & $\checkmark$ & $\checkmark$ \\
\hline October 4, 2001 & 5 & Defensive Shield & $\checkmark$ & \\
\hline February 7, 2002 & 6 & & $\checkmark$ & $\checkmark$ \\
\hline May 21, 2002 & 7 & & & $\checkmark$ \\
\hline July 31, 2002 & 8 & & $\checkmark$ & $\checkmark$ \\
\hline February 6, 2003 & 10 & Phase 2: Between & $\checkmark$ & $\checkmark$ \\
\hline May 8, 2003 & 12 & Operation & & $\checkmark$ \\
\hline July 24, 2003 & 13 & Defensive Shield & $\checkmark$ & \\
\hline October 10,2003 & 14 & and Arafat's death & $\checkmark$ & $\checkmark$ \\
\hline June 4, 2004 & 16 & & $\checkmark$ & $\checkmark$ \\
\hline September 9, 2004 & 18 & & $\checkmark$ & $\checkmark$ \\
\hline December 3, 2004 & 20 & & $\checkmark$ & $\checkmark$ \\
\hline September 30, 2005 & 22 & & $\checkmark$ & \\
\hline March 27, 2006 & 25 & & $\checkmark$ & \\
\hline April 19, 2006 & 26 & Phase 3: After & $\checkmark$ & \\
\hline May 31, 2006 & 27 & & $\checkmark$ & \\
\hline September 14, 2006 & 28 & & & $\checkmark$ \\
\hline February 22, 2007 & 30 & & $\checkmark$ & \\
\hline Total number of polls & & & 17 & 12 \\
\hline Total $N$ & & & 19,904 & 13,692 \\
\hline
\end{tabular}


Table 2

Attitudes Towards the Conflict and Suport for Different Factions

\begin{tabular}{|c|c|c|c|c|c|c|}
\hline \multirow[b]{2}{*}{ Attitudes } & \multirow[b]{2}{*}{$N$} & \multicolumn{5}{|c|}{$\begin{array}{c}\text { Percentage in favor of moderate position } \\
\text { among supporters of: }\end{array}$} \\
\hline & & Fatah & Hamas & Others & No one & All \\
\hline \multicolumn{7}{|l|}{ DSP Data } \\
\hline Support for peace negotiations & 9,724 & 72.0 & 48.0 & 53.3 & 61.3 & 59.6 \\
\hline \multicolumn{7}{|l|}{ JMCC Data } \\
\hline Preferred solution to the conflict: NOT Islamic/Palestinian state & 12,250 & 92.0 & 76.4 & 80.8 & 88.7 & 85.6 \\
\hline Opposes continuation of the Intifada & 8,550 & 30.4 & 13.6 & 16.5 & 31.9 & 21.7 \\
\hline Opposes resumption of military operations & 11,447 & 51.6 & 26.4 & 30.2 & 43.9 & 36.8 \\
\hline Opposes suicide bombings & 9,500 & 49.5 & 24.4 & 32.5 & 46.2 & 35.6 \\
\hline
\end{tabular}

Source: Authors' calculations using poll data from DSP and JMCC. 
Table 3

Summary Statistics of Palestinian and Israeli Fatalities

\begin{tabular}{|c|c|c|c|c|c|}
\hline \multirow[b]{2}{*}{ Area } & \multicolumn{2}{|c|}{$\begin{array}{c}\text { Average Palestinian Fatalities } \\
\text { within } 90 \text { Days Prior to a Poll } \\
\text { by District of Fatality }\end{array}$} & \multicolumn{3}{|c|}{$\begin{array}{l}\text { Average Israeli Fatalities within } 90 \text { Days Prior } \\
\text { to a Poll, by District and Affiliation of Attacker }\end{array}$} \\
\hline & All & $\begin{array}{l}\text { Targeted } \\
\text { Killings } \\
\end{array}$ & All & Fatah & Hamas \\
\hline Jerusalem & $\begin{array}{c}1.28 \\
(1.46)\end{array}$ & 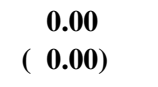 & $\begin{array}{c}2.88 \\
(5.83)\end{array}$ & $\begin{array}{c}0.92 \\
(1.55)\end{array}$ & $\begin{array}{c}1.88 \\
(4.65)\end{array}$ \\
\hline \multicolumn{6}{|l|}{ West Bank } \\
\hline Jenin & $\begin{array}{c}13.72 \\
(16.56)\end{array}$ & $\begin{array}{l}0.56 \\
(1.19)\end{array}$ & $\begin{array}{c}7.80 \\
(12.81)\end{array}$ & $\begin{array}{l}1.96 \\
(4.64)\end{array}$ & $\begin{array}{l}1.28 \\
(4.87)\end{array}$ \\
\hline Toubas & $\begin{array}{c}1.88 \\
(3.09)\end{array}$ & $\begin{array}{c}0.56 \\
(1.61)\end{array}$ & $\begin{array}{c}0.16 \\
(0.62)\end{array}$ & $\begin{array}{l}0.00 \\
(0.00)\end{array}$ & $\begin{array}{c}0.04 \\
(0.20)\end{array}$ \\
\hline Tulkarem & $\begin{array}{c}7.12 \\
(7.41)\end{array}$ & $\begin{array}{l}0.40 \\
(0.91)\end{array}$ & $\begin{array}{l}3.16 \\
(5.01)\end{array}$ & $\begin{array}{l}0.60 \\
(1.19)\end{array}$ & $\begin{array}{c}1.40 \\
(3.69)\end{array}$ \\
\hline Nablus & $\begin{array}{c}17.92 \\
(20.29)\end{array}$ & $\begin{array}{c}0.72 \\
(2.01)\end{array}$ & $\begin{array}{c}6.60 \\
(12.46)\end{array}$ & $\begin{array}{l}2.68 \\
(5.14)\end{array}$ & $\begin{array}{l}3.00 \\
(8.72)\end{array}$ \\
\hline Qalqilya & $\begin{array}{l}1.96 \\
(2.86)\end{array}$ & $\begin{array}{l}0.00 \\
(0.00)\end{array}$ & $\begin{array}{l}1.00 \\
(2.40)\end{array}$ & $\begin{array}{l}0.08 \\
(0.28)\end{array}$ & $\begin{array}{c}0.76 \\
(2.40)\end{array}$ \\
\hline Salfeet & $\begin{array}{l}1.00 \\
(2.10)\end{array}$ & $\begin{array}{l}0.08 \\
(0.40)\end{array}$ & $\begin{array}{ll} & 0.08 \\
(0.40)\end{array}$ & $\begin{array}{l}0.00 \\
(0.00)\end{array}$ & $\begin{array}{ll}0.08 \\
(0.40)\end{array}$ \\
\hline Jericho & $\begin{array}{l}1.00 \\
(1.08)\end{array}$ & $\begin{array}{l}0.00 \\
(0.00)\end{array}$ & $\begin{array}{l}0.48 \\
(0.92)\end{array}$ & $\begin{array}{l}0.16 \\
(0.37)\end{array}$ & $\begin{array}{c}0.12 \\
(0.60)\end{array}$ \\
\hline Ramallah & $\begin{array}{c}6.96 \\
(13.84)\end{array}$ & $\begin{array}{c}0.20 \\
(0.82)\end{array}$ & $\begin{array}{c}2.68 \\
(4.60)\end{array}$ & $\begin{array}{c}1.64 \\
(3.28)\end{array}$ & $\begin{array}{c}0.76 \\
(3.19)\end{array}$ \\
\hline Bethlehem & $\begin{array}{c}3.92 \\
(7.61)\end{array}$ & $\begin{array}{c}0.48 \\
(1.12)\end{array}$ & $\begin{array}{c}2.24 \\
(5.17)\end{array}$ & $\begin{array}{c}1.60 \\
(4.79)\end{array}$ & $\begin{array}{c}0.48 \\
(2.20)\end{array}$ \\
\hline Hebron & $\begin{array}{c}6.64 \\
(8.70)\end{array}$ & $\begin{array}{c}0.24 \\
(0.52)\end{array}$ & $\begin{array}{c}5.68 \\
(8.93)\end{array}$ & $\begin{array}{c}0.64 \\
(1.22)\end{array}$ & $\begin{array}{c}4.00 \\
(7.51)\end{array}$ \\
\hline Total & $\begin{array}{c}62.12 \\
(74.99)\end{array}$ & $\begin{array}{c}3.24 \\
(4.55)\end{array}$ & $\begin{array}{c}29.88 \\
(36.85)\end{array}$ & $\begin{array}{c}9.36 \\
(15.71)\end{array}$ & $\begin{array}{c}11.92 \\
(17.89)\end{array}$ \\
\hline \multicolumn{6}{|l|}{ Gaza Strip } \\
\hline Gaza North & $\begin{array}{c}24.28 \\
(34.39)\end{array}$ & $\begin{array}{c}1.60 \\
(3.98)\end{array}$ & $\begin{array}{c}1.00 \\
(1.44)\end{array}$ & $\begin{array}{c}0.04 \\
(0.20)\end{array}$ & $\begin{array}{c}0.72 \\
(1.34)\end{array}$ \\
\hline Gaza City & $\begin{array}{c}22.84 \\
(21.01)\end{array}$ & $\begin{array}{c}7.96 \\
(8.59)\end{array}$ & $\begin{array}{l}1.48 \\
(3.40)\end{array}$ & $\begin{array}{l}0.76 \\
(2.18)\end{array}$ & $\begin{array}{c}0.56 \\
(1.61)\end{array}$ \\
\hline Deir El-Balah & $\begin{array}{c}10.00 \\
(9.71)\end{array}$ & $\begin{array}{c}0.04 \\
(0.20)\end{array}$ & $\begin{array}{c}0.36 \\
(0.81)\end{array}$ & $\begin{array}{l}0.04 \\
(0.20)\end{array}$ & $\begin{array}{c}0.00 \\
(0.00)\end{array}$ \\
\hline Khan Younis & $\begin{array}{c}13.76 \\
(11.93)\end{array}$ & $\begin{array}{c}0.88 \\
(1.45)\end{array}$ & $\begin{array}{l}1.52 \\
(2.65)\end{array}$ & $\begin{array}{l}0.48 \\
(1.87)\end{array}$ & $\begin{array}{c}0.44 \\
(1.08)\end{array}$ \\
\hline Rafah & $\begin{array}{c}14.56 \\
(15.20)\end{array}$ & $\begin{array}{c}0.72 \\
(1.57)\end{array}$ & $\begin{array}{c}0.96 \\
(2.47)\end{array}$ & $\begin{array}{c}0.04 \\
(0.20)\end{array}$ & $\begin{array}{c}0.28 \\
(0.89)\end{array}$ \\
\hline Total & $\begin{array}{c}85.44 \\
(68.97)\end{array}$ & $\begin{array}{c}11.20 \\
(9.45)\end{array}$ & $\begin{array}{c}5.32 \\
(6.63)\end{array}$ & $\begin{array}{c}1.36 \\
(2.94)\end{array}$ & $\begin{array}{c}2.00 \\
(2.45)\end{array}$ \\
\hline Total for All Areas & $\begin{array}{c}148.84 \\
(116.86)\end{array}$ & $\begin{array}{c}14.44 \\
\text { ( } 9.19)\end{array}$ & $\begin{array}{c}38.08 \\
(43.29)\end{array}$ & $\begin{array}{c}11.64 \\
(17.31)\end{array}$ & $\begin{array}{c}15.80 \\
(22.46)\end{array}$ \\
\hline
\end{tabular}

Source: Authors' calculations using data from B'Tselem, linked to dates of polls from DSP.

Note: Standard deviations in parentheses. 
Table 4

Summary Statistics of Palestinian and Israeli Fatalities

\begin{tabular}{lccc}
\hline Time period & $\begin{array}{c}\text { Palestinian } \\
\text { fatalities per } \\
\text { district }\end{array}$ & $\begin{array}{c}\text { Israeli fatalities } \\
\text { per district }\end{array}$ & $\begin{array}{c}\text { Israeli fatalities, } \\
\text { overall }\end{array}$ \\
\hline Total, 1-4 weeks before poll & 2.26 & 0.56 & 8.88 \\
& $(4.66)$ & $(2.12)$ & $(8.53)$ \\
Total, 5-8 weeks before poll & 3.15 & 0.95 & 15.12 \\
Total, 9-12 weeks before poll & $(7.82)$ & $(4.07)$ & $(23.42)$ \\
& 3.31 & 0.74 & 11.76 \\
$N$ & $(7.15)$ & $(2.34)$ & $(16.18)$ \\
\hline
\end{tabular}

Source: Authors' calculations using data from B'Tselem, linked to dates of polls from DSP. Note: Standard deviations in parentheses. 
Table 5

Faction Support by Demographic Characteristics

\begin{tabular}{|c|c|c|c|c|c|}
\hline \multirow[b]{2}{*}{ Demographic Charactistic } & \multicolumn{4}{|c|}{ Share supporting: } & \multirow{2}{*}{$\begin{array}{c}\text { Fatah share out } \\
\text { of Fatah/Hamas } \\
\text { alone }\end{array}$} \\
\hline & Fatah & Hamas & Others & No one & \\
\hline All & 29.12 & 22.64 & 19.88 & 28.36 & 56.26 \\
\hline \multicolumn{6}{|l|}{ Area of residence } \\
\hline Jerusalem & 19.87 & 19.67 & 20.57 & 39.89 & 50.26 \\
\hline West Bank & 30.06 & 21.50 & 21.28 & 27.16 & 58.30 \\
\hline Gaza Strip & 29.65 & 24.86 & 17.76 & 27.73 & 54.40 \\
\hline \multicolumn{6}{|l|}{ Type of residence } \\
\hline Cities & 28.10 & 23.81 & 18.88 & 29.21 & 54.13 \\
\hline Villages & 29.57 & 20.72 & 21.36 & 28.35 & 58.80 \\
\hline Refugee camps & 30.40 & 24.25 & 18.88 & 26.47 & 55.63 \\
\hline \multicolumn{6}{|l|}{ Refugee Status } \\
\hline Non-refugees & 28.19 & 21.98 & 20.58 & 29.25 & 56.18 \\
\hline Refugees & 29.94 & 22.34 & 19.35 & 28.37 & 57.26 \\
\hline \multicolumn{6}{|l|}{ Gender } \\
\hline Males & 33.70 & 18.32 & 21.96 & 26.02 & 64.79 \\
\hline Females & 24.67 & 26.85 & 17.86 & 30.62 & 47.89 \\
\hline \multicolumn{6}{|l|}{ Marital Status } \\
\hline Married & 28.39 & 21.90 & 19.98 & 29.73 & 56.45 \\
\hline Non-married & 30.87 & 22.74 & 20.63 & 25.76 & 57.59 \\
\hline \multicolumn{6}{|l|}{ Age } \\
\hline $15-29$ & 29.59 & 24.69 & 19.94 & 25.77 & 54.52 \\
\hline $30-44$ & 31.12 & 22.78 & 19.95 & 26.15 & 57.73 \\
\hline $45-59$ & 26.84 & 20.42 & 20.26 & 32.48 & 56.80 \\
\hline$\geq 60$ & 22.89 & 17.30 & 18.49 & 41.32 & 56.96 \\
\hline \multicolumn{6}{|l|}{ Education } \\
\hline Illiterate & 25.56 & 19.37 & 17.57 & 37.50 & 56.88 \\
\hline Elementary & 30.43 & 23.51 & 17.18 & 28.89 & 56.42 \\
\hline Middle school & 28.13 & 25.48 & 19.60 & 26.79 & 52.47 \\
\hline Secondary & 30.41 & 23.80 & 19.84 & 25.95 & 56.10 \\
\hline Some college & 30.24 & 19.79 & 22.77 & 27.20 & 60.44 \\
\hline College degree & 30.23 & 16.64 & 25.99 & 27.13 & 64.50 \\
\hline \multicolumn{6}{|l|}{ Local Unemployment Rate } \\
\hline$\leq 30 \%$ & 30.21 & 23.56 & 19.23 & 26.99 & 56.19 \\
\hline $30 \%-40 \%$ & 30.38 & 21.7 & 19.85 & 28.08 & 58.33 \\
\hline$\geq 40 \%$ & 26.01 & 22.79 & 20.75 & 30.45 & 53.29 \\
\hline \multicolumn{6}{|l|}{ Daily wage (in year 2000 NIS) } \\
\hline$\leq 55$ NIS & 26.83 & 21.79 & 18.47 & 32.91 & 55.18 \\
\hline 55 NIS - 65 NIS & 31.69 & 24.44 & 18.13 & 25.75 & 56.46 \\
\hline$\geq 65$ NIS & 26.46 & 20.28 & 23.66 & 29.61 & 56.61 \\
\hline
\end{tabular}

Source: Authors' calculations using poll data from DSP. 
Table 6A

The Effect of Violence on Support for Fatah

\begin{tabular}{|c|c|c|c|c|c|}
\hline Variable & $(1)$ & $(2)$ & $(3)$ & (4) & $(5)$ \\
\hline \multicolumn{6}{|l|}{ Palestinian fatalities prior to poll (100s): } \\
\hline - 1 to 12 weeks & $\begin{array}{c}0.025 \\
{[0.038]}\end{array}$ & & & & \\
\hline-1 to 4 weeks & & $\begin{array}{l}-0.149 * * \\
{[0.071]}\end{array}$ & $\begin{array}{l}-0.229 * * * \\
{[0.074]}\end{array}$ & $\begin{array}{l}-0.220 * * \\
{[0.109]}\end{array}$ & $\begin{array}{c}-0.084 \\
{[0.066]}\end{array}$ \\
\hline - 5 to 8 weeks & & $\begin{array}{c}-0.098 \\
{[0.110]}\end{array}$ & $\begin{array}{l}-0.118 \\
{[0.124]}\end{array}$ & $\begin{array}{c}-0.171 \\
{[0.179]}\end{array}$ & $\begin{array}{l}-0.028 \\
{[0.090]}\end{array}$ \\
\hline - 9 to 12 weeks & & $\begin{array}{l}0.150 * * * \\
{[0.044]}\end{array}$ & $\begin{array}{l}0.138 * * * \\
{[0.046]}\end{array}$ & $\begin{array}{l}0.201 * * * \\
{[0.067]}\end{array}$ & $\begin{array}{c}0.041 \\
{[0.036]}\end{array}$ \\
\hline Long-run effect of Palestinian fatalities & $\begin{array}{c}0.295 \\
{[0.450]}\end{array}$ & $\begin{array}{l}-0.392 \\
{[0.510]}\end{array}$ & $\begin{array}{l}-0.837 \\
{[0.554]}\end{array}$ & $\begin{array}{l}-0.758 \\
{[0.879]}\end{array}$ & $\begin{array}{l}-0.280 \\
{[0.443]}\end{array}$ \\
\hline \multicolumn{6}{|l|}{ Local Israeli fatalities prior to poll (100s): } \\
\hline - 1 to 12 weeks & $\begin{array}{c}0.039 \\
{[0.084]}\end{array}$ & & & & \\
\hline-1 to 4 weeks & & $\begin{array}{c}-0.059 \\
{[0.123]}\end{array}$ & $\begin{array}{l}-0.225 * * \\
{[0.092]}\end{array}$ & $\begin{array}{c}-0.274 \\
{[0.179]}\end{array}$ & $\begin{array}{c}-0.144 \\
{[0.103]}\end{array}$ \\
\hline - 5 to 8 weeks & & $\begin{array}{c}0.180 * \\
{[0.104]}\end{array}$ & $\begin{array}{c}0.107 * \\
{[0.093]}\end{array}$ & $\begin{array}{c}0.165 \\
{[0.108]}\end{array}$ & $\begin{array}{c}0.186 * \\
{[0.105]}\end{array}$ \\
\hline - 9 to 12 weeks & & $\begin{array}{c}-0.043 \\
{[0.155]}\end{array}$ & $\begin{array}{c}-0.024 \\
{[0.174]}\end{array}$ & $\begin{array}{c}-0.110 \\
{[0.168]}\end{array}$ & $\begin{array}{c}-0.074 \\
{[0.124]}\end{array}$ \\
\hline Long-run effect of Israeli fatalities & $\begin{array}{c}0.464 \\
{[1.009]}\end{array}$ & $\begin{array}{c}0.313 \\
{[0.928]}\end{array}$ & $\begin{array}{l}-0.571 \\
{[0.837]}\end{array}$ & $\begin{array}{l}-0.875 \\
{[1.167]}\end{array}$ & $\begin{array}{l}-0.130 \\
{[0.802]}\end{array}$ \\
\hline Daily wage & $\begin{array}{c}0.001 \\
{[0.001]}\end{array}$ & $\begin{array}{c}0.001 \\
{[0.001]}\end{array}$ & $\begin{array}{l}-0.003 * * * \\
{[0.000]}\end{array}$ & $\begin{array}{c}0.001 \\
{[0.001]}\end{array}$ & $\begin{array}{c}0.002 \\
{[0.001]}\end{array}$ \\
\hline Local unemployment rate & $\begin{array}{l}-0.192 * * * \\
{[0.070]}\end{array}$ & $\begin{array}{l}-0.202 * * * \\
{[0.070]}\end{array}$ & $\begin{array}{l}-0.102 * \\
{[0.056]}\end{array}$ & $\begin{array}{l}-0.630 * * * \\
{[0.086]}\end{array}$ & $\begin{array}{l}-0.048 \\
{[0.076]}\end{array}$ \\
\hline Closure days out of past 30 days & $\begin{array}{l}-0.0006 \\
{[0.0005]}\end{array}$ & $\begin{array}{l}-0.0006 \\
{[0.0004]} \\
\end{array}$ & $\begin{array}{l}-0.0002 \\
{[0.0005]} \\
\end{array}$ & $\begin{array}{l}-0.0013 * \\
{[0.0007]}\end{array}$ & $\begin{array}{c}0.0005 \\
{[0.0006]} \\
\end{array}$ \\
\hline District Fixed Effects & Yes & Yes & No & Yes & Yes \\
\hline Time Effects & $\begin{array}{l}\text { Two period } \\
\text { dummies }\end{array}$ & $\begin{array}{l}\text { Two period } \\
\text { dummies }\end{array}$ & $\begin{array}{l}\text { Two period } \\
\text { dummies }\end{array}$ & $\begin{array}{l}\text { No time } \\
\text { dummies }\end{array}$ & $\begin{array}{c}13 \text { poll } \\
\text { dummies }\end{array}$ \\
\hline$N$ & 16,474 & 16,474 & 16,474 & 16,474 & 16,474 \\
\hline$R^{2}$ & 0.042 & 0.043 & 0.039 & 0.030 & 0.047 \\
\hline Number of poll $\times$ district clusters & 221 & 221 & 221 & 221 & 221 \\
\hline
\end{tabular}

Source: Authors' calculations using fatality data from B'Tselem, poll data from DSP, labor market data from the Palestinian Labor Force Survey and border closures data from the Palestinian Ministry of Labor.

Note: Estimated via OLS. Dependent variable is an indicator variable for supporting Fatah. All regressions include controls for residence type, gender, age, marital status, refugee status, education dummies, local unemployment rate, the local wage rate, the number of closure days in the 30 days preceding the poll. In columns 1-3, the two period dummies are for Phases 2 and 3 of the conflict, as defined in Table 1. Robust standard errors, adjusted for clustering at the poll-district level, in brackets; * indicates statistically significant at $10 \%$ level, ** indicates statistically significant at $5 \%$ level; *** indicates statistically significant at $1 \%$ level. 
Table 6B

The Effect of Violence on Support for Negotiations with Israel

\begin{tabular}{|c|c|c|c|c|c|}
\hline Variable & $(1)$ & $(2)$ & $(3)$ & $(4)$ & $(5)$ \\
\hline \multicolumn{6}{|l|}{ Palestinian fatalities prior to poll (100s): } \\
\hline - 1 to 12 weeks & $\begin{array}{c}0.042 \\
{[0.049]}\end{array}$ & & & & \\
\hline-1 to 4 weeks & & $\begin{array}{l}-0.238 * * \\
{[0.119]}\end{array}$ & $\begin{array}{l}-0.303 * * * \\
{[0.105]}\end{array}$ & $\begin{array}{l}-0.285 * * \\
{[0.128]}\end{array}$ & $\begin{array}{c}0.019 \\
{[0.085]}\end{array}$ \\
\hline - 5 to 8 weeks & & $\begin{array}{l}-0.088 \\
{[0.106]}\end{array}$ & $\begin{array}{l}-0.074 \\
{[0.097]}\end{array}$ & $\begin{array}{l}-0.037 \\
{[0.120]}\end{array}$ & $\begin{array}{l}-0.050 \\
{[0.072]}\end{array}$ \\
\hline - 9 to 12 weeks & & $\begin{array}{l}0.209 * * \\
{[0.087]}\end{array}$ & $\begin{array}{l}0.181 * * * \\
{[0.070]}\end{array}$ & $\begin{array}{l}0.332 * * * \\
{[0.099]}\end{array}$ & $\begin{array}{c}0.063 \\
{[0.054]}\end{array}$ \\
\hline Long-run effect of Palestinian fatalities & $\begin{array}{c}0.499 \\
{[0.586]}\end{array}$ & $\begin{array}{l}-0.470 \\
{[0.699]}\end{array}$ & $\begin{array}{l}-0.789 \\
{[0.601]}\end{array}$ & $\begin{array}{c}0.039 \\
{[0.792]}\end{array}$ & $\begin{array}{c}0.129 \\
{[0.569]}\end{array}$ \\
\hline \multicolumn{6}{|l|}{ Local Israeli fatalities prior to poll (100s): } \\
\hline - 1 to 12 weeks & $\begin{array}{c}-0.136 \\
{[0.129]}\end{array}$ & & & & \\
\hline-1 to 4 weeks & & $\begin{array}{c}-0.161 \\
{[0.241]}\end{array}$ & $\begin{array}{c}-0.262 \\
{[0.202]}\end{array}$ & $\begin{array}{c}-0.256 \\
{[0.245]}\end{array}$ & $\begin{array}{l}-0.340 * * * \\
{[0.125]}\end{array}$ \\
\hline-5 to 8 weeks & & $\begin{array}{c}-0.057 \\
{[0.133]}\end{array}$ & $\begin{array}{c}-0.089 \\
{[0.081]}\end{array}$ & $\begin{array}{c}-0.141 \\
{[0.131]}\end{array}$ & $\begin{array}{l}-0.187 * * \\
{[0.086]}\end{array}$ \\
\hline - 9 to 12 weeks & & $\begin{array}{c}0.039 \\
{[0.236]}\end{array}$ & $\begin{array}{c}0.009 \\
{[0.181]}\end{array}$ & $\begin{array}{c}-0.034 \\
{[0.244]}\end{array}$ & $\begin{array}{c}-0.246 \\
{[0.157]}\end{array}$ \\
\hline Long-run effect of Israeli fatalities & $\begin{array}{l}-1.630 \\
{[1.551]}\end{array}$ & $\begin{array}{l}-0.714 \\
{[1.837]}\end{array}$ & $\begin{array}{l}-1.369 \\
{[1.203]}\end{array}$ & $\begin{array}{l}-1.721 \\
{[1.905]}\end{array}$ & $\begin{array}{l}-3.091 * * * \\
{[0.989]}\end{array}$ \\
\hline Daily wage & $\begin{array}{l}-0.004 * * \\
{[0.002]}\end{array}$ & $\begin{array}{l}-0.004 * * \\
{[0.002]}\end{array}$ & $\begin{array}{l}-0.001 * \\
{[0.001]}\end{array}$ & $\begin{array}{c}-0.003 \\
{[0.002]}\end{array}$ & $\begin{array}{c}-0.000 \\
{[0.001]}\end{array}$ \\
\hline Local unemployment rate & $\begin{array}{c}0.118 \\
{[0.134]}\end{array}$ & $\begin{array}{c}0.081 \\
{[0.125]}\end{array}$ & $\begin{array}{c}0.026 \\
{[0.102]}\end{array}$ & $\begin{array}{c}-0.097 \\
{[0.128]}\end{array}$ & $\begin{array}{c}0.156 \\
{[0.116]}\end{array}$ \\
\hline Closure days out of past 30 days & $\begin{array}{c}0.0012 \\
{[0.0009]}\end{array}$ & $\begin{array}{c}0.0009 \\
{[0.0009]}\end{array}$ & $\begin{array}{c}0.0011 \\
{[0.0008]}\end{array}$ & $\begin{array}{l}-0.0002 \\
{[0.0010]}\end{array}$ & $\begin{array}{c}0.0035 \\
{[0.0010]} \\
\end{array}$ \\
\hline District Fixed Effects & Yes & Yes & No & Yes & Yes \\
\hline Time Effects & $\begin{array}{l}\text { Two period } \\
\text { dummies }\end{array}$ & $\begin{array}{c}\text { Two period } \\
\text { dummies }\end{array}$ & $\begin{array}{l}\text { Two period } \\
\text { dummies }\end{array}$ & $\begin{array}{l}\text { No time } \\
\text { dummies }\end{array}$ & $\begin{array}{c}13 \text { poll } \\
\text { dummies }\end{array}$ \\
\hline$N$ & 11,969 & 11,969 & 11,969 & 11,969 & 11,969 \\
\hline$R^{2}$ & 0.032 & 0.033 & 0.029 & 0.028 & 0.052 \\
\hline Number of poll $\times$ district clusters & 174 & 174 & 174 & 174 & 174 \\
\hline
\end{tabular}

Source: Authors' calculations using fatality data from B'Tselem, poll data from DSP, labor market data from the Palestinian Labor Force Survey and border closures data from the Palestinian Ministry of Labor.

Note: Estimated via OLS. Dependent variable is an indicator variable for supporting Fatah. All regressions include controls for residence type, gender, age, marital status, refugee status, education dummies, local unemployment rate, the local wage rate, the number of closure days in the 30 days preceding the poll. In columns 1-3, the two period dummies are for Phases 2 and 3 of the conflict, as defined in Table 1. Robust standard errors, adjusted for clustering at the poll-district level, in brackets; * indicates statistically significant at $10 \%$ level, ** indicates statistically significant at $5 \%$ level; *** indicates statistically significant at $1 \%$ level. 
Table 7

The Effect of Violence on Support for Fatah and Peace Negotiations: West Bank and Gaza

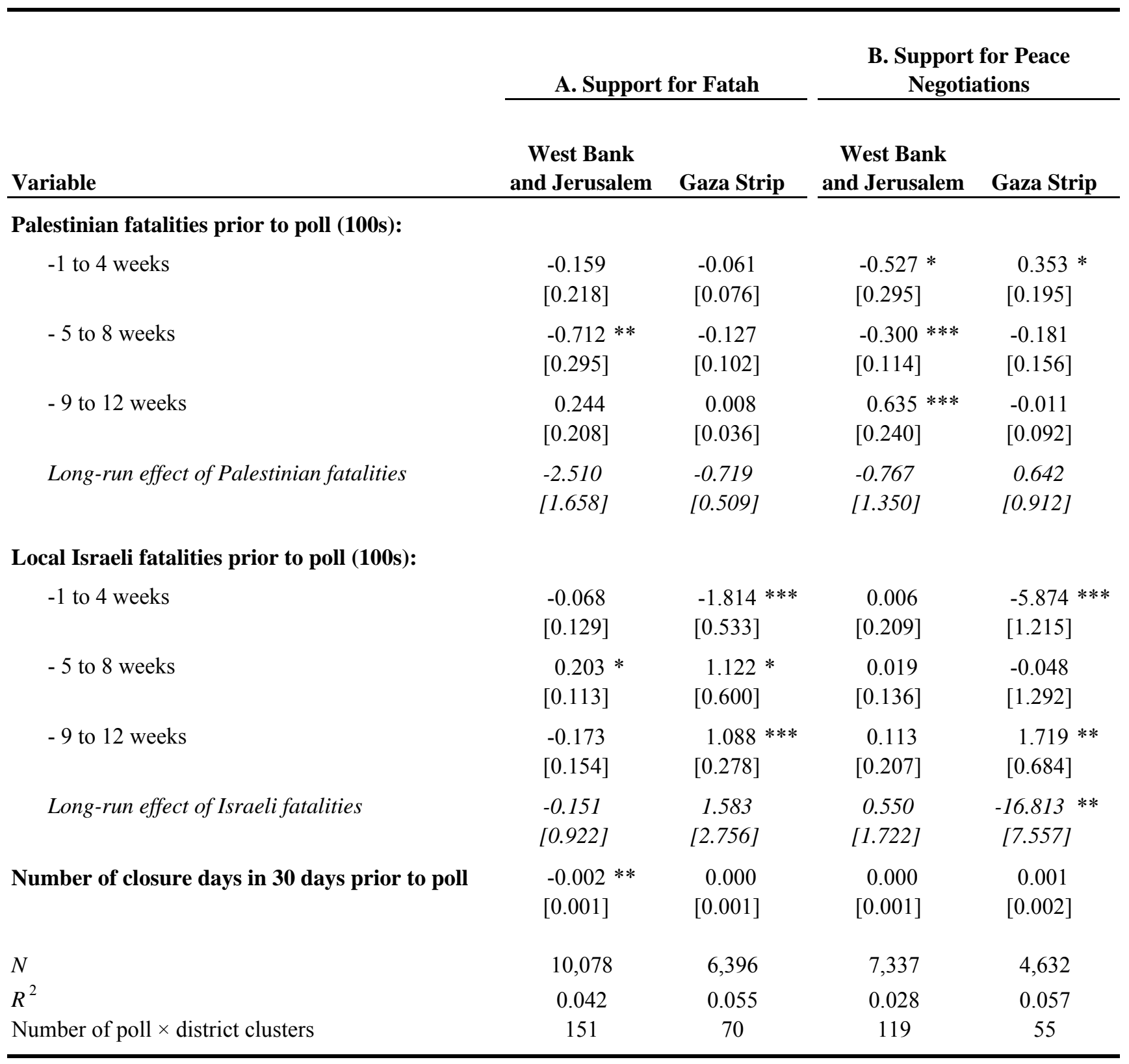

Source: Authors' calculations using fatality data from B'Tselem, poll data from DSP and the Jerusalem Media and Communications Center, labor market data from the Palestinian Labor Force Survey and border closures data from the Palestinian Ministry of Labor.

Note: Estimated via OLS. Dependent variable is an indicator for supporting Fatah or support for peace negotiations. All regressions include controls for residence type, gender, age, marital status, refugee status, education dummies, local unemployment rate, the local wage rate, period dummies, and district fixed effects. Robust standard errors, adjusted for clustering at the poll-district level, in brackets; * indicates statistically significant at $10 \%$ level, ** indicates statistically significant at 5\% level; *** indicates statistically significant at $1 \%$ level. 
Table 8

The Effect of Violence on Support for Fatah and Peace Negotiations: Local and Non-Local Fatalities

\begin{tabular}{|c|c|c|c|c|}
\hline \multirow[b]{2}{*}{ Variable } & \multicolumn{2}{|c|}{ A. Support for Fatah } & \multicolumn{2}{|c|}{$\begin{array}{l}\text { B. Support for Peace } \\
\text { Negotiations }\end{array}$} \\
\hline & $(1)$ & $(2)$ & (3) & (4) \\
\hline \multicolumn{5}{|l|}{ Palestinian fatalities prior to poll (100s), local: } \\
\hline-1 to 4 weeks & $\begin{array}{l}-0.115 * \\
{[0.063]}\end{array}$ & $\begin{array}{l}-0.119 * \\
{[0.062]}\end{array}$ & $\begin{array}{l}-0.354 * * * \\
{[0.086]}\end{array}$ & $\begin{array}{l}-0.363 * * * \\
{[0.081]}\end{array}$ \\
\hline-5 to 8 weeks & $\begin{array}{l}-0.279 * * * \\
{[0.108]}\end{array}$ & $\begin{array}{l}-0.305 * * * \\
{[0.119]}\end{array}$ & $\begin{array}{l}0.198 * \\
{[0.123]}\end{array}$ & $\begin{array}{l}0.317 * * \\
{[0.129]}\end{array}$ \\
\hline - 9 to 12 weeks & $\begin{array}{l}0.172 * * * \\
{[0.045]}\end{array}$ & $\begin{array}{l}0.196 * * * \\
{[0.055]}\end{array}$ & $\begin{array}{l}-0.159 * \\
{[0.089]}\end{array}$ & $\begin{array}{l}-0.222 * * * \\
{[0.084]}\end{array}$ \\
\hline Long-run effect of local Palestinian fatalities & $\begin{array}{l}-0.887 * \\
{[0.466]}\end{array}$ & $\begin{array}{l}-0.908 * * \\
{[0.458]}\end{array}$ & $\begin{array}{l}-1.261 * * * \\
{[0.537]}\end{array}$ & $\begin{array}{l}-1.074 * * \\
{[0.500]}\end{array}$ \\
\hline \multicolumn{5}{|l|}{ Palestinian fatalities prior to poll (100s), all other districts: } \\
\hline-1 to 4 weeks & $\begin{array}{l}-0.012 \\
{[0.022]}\end{array}$ & & $\begin{array}{l}-0.374 * * * \\
{[0.040]}\end{array}$ & \\
\hline-5 to 8 weeks & $\begin{array}{l}-0.253 * * * \\
{[0.071]}\end{array}$ & & $\begin{array}{l}0.245^{* *} \\
{[0.100]}\end{array}$ & \\
\hline - 9 to 12 weeks & $\begin{array}{l}0.138 * * * \\
{[0.030]}\end{array}$ & & $\begin{array}{l}-0.253 * * * \\
{[0.084]}\end{array}$ & \\
\hline Long-run effect of Palestinian fatalities in other districts & $\begin{array}{l}-0.508 * * * \\
{[0.159]}\end{array}$ & & $\begin{array}{l}-1.526 * * * \\
{[0.141]}\end{array}$ & \\
\hline \multicolumn{5}{|l|}{ Palestinian fatalities prior to poll (100s), other districts in same } \\
\hline-1 to 4 weeks & & $\begin{array}{l}-0.026 \\
{[0.030]}\end{array}$ & & $\begin{array}{l}-0.392 * * * \\
{[0.060]}\end{array}$ \\
\hline-5 to 8 weeks & & $\begin{array}{l}-0.297 * * * \\
{[0.098]}\end{array}$ & & $\begin{array}{l}0.333 * * * \\
{[0.107]}\end{array}$ \\
\hline - 9 to 12 weeks & & $\begin{array}{l}0.155 * * * \\
{[0.047]}\end{array}$ & & $\begin{array}{l}-0.250 * * * \\
{[0.081]}\end{array}$ \\
\hline $\begin{array}{l}\text { Long-run effect of Palestinian fatalities, other districts in same } \\
\text { region }\end{array}$ & & $\begin{array}{l}-0.674 * * * \\
{[0.260]}\end{array}$ & & $\begin{array}{l}-1.237 * * * \\
{[0.275]}\end{array}$ \\
\hline \multicolumn{5}{|l|}{ Palestinian fatalities prior to poll (100s), other regions: } \\
\hline-1 to 4 weeks & & $\begin{array}{l}-0.004 \\
{[0.034]}\end{array}$ & & $\begin{array}{l}-0.369 * * * \\
{[0.049]}\end{array}$ \\
\hline-5 to 8 weeks & & $\begin{array}{l}-0.225 * * * \\
{[0.086]}\end{array}$ & & $\begin{array}{l}0.410 * * * \\
{[0.111]}\end{array}$ \\
\hline - 9 to 12 weeks & & $\begin{array}{l}0.121 * * * \\
{[0.045]}\end{array}$ & & $\begin{array}{l}-0.403 * * * \\
{[0.102]}\end{array}$ \\
\hline Long-run effect of Palestinian fatalities in other regions & & $\begin{array}{l}-0.432 * \\
{[0.222]}\end{array}$ & & $\begin{array}{l}-1.445 * * * \\
{[0.246]}\end{array}$ \\
\hline$N$ & 16,474 & 16,474 & 11,969 & 11,969 \\
\hline$R^{2}$ & 0.046 & 0.046 & 0.051 & 0.052 \\
\hline Number of poll $\times$ district clusters & 221 & 221 & 174 & 174 \\
\hline
\end{tabular}

Source: Authors' calculations using fatality data from B'Tselem, poll data from DSP, labor market data from the Palestinian Labor Force Survey and border closures data from the Palestinian Ministry of Labor.

Note: Estimated via OLS. Dependent variable is indicator for supporting Fatah or support for peace negotiations. All regressions include controls for overall number of Israeli fatalities, residence type, gender, age, marital status, refugee status, religion, education dummies, local unemployment rate, the local wage rate, the number of closure days in the 30 days preceding the poll, period dummies, and 15 district fixed effects. Robust standard errors, adjusted for clustering at the poll-district level, in brackets; * indicates statistically significant at $10 \%$ level, $* *$ indicates statistically significant at $5 \%$ level; *** indicates statistically significant at $1 \%$ level. 
Table 9

The Effect of Violence on Support for Fatah and Peace Negotiations: Targeted Killings and Other Fatalities

\begin{tabular}{|c|c|c|c|c|}
\hline \multirow[b]{2}{*}{ Variable } & \multicolumn{2}{|c|}{ A. Support for Fatah } & \multicolumn{2}{|c|}{$\begin{array}{l}\text { B. Support for Peace } \\
\text { Negotiations } \\
\end{array}$} \\
\hline & (1) & (2) & (3) & (4) \\
\hline \multicolumn{5}{|l|}{ Palestinian fatalities not in targeted killlings prior to poll (100s) } \\
\hline-1 to 4 weeks & $\begin{array}{l}-0.161 * * \\
{[0.075]}\end{array}$ & $\begin{array}{l}-0.158 * * \\
{[0.073]}\end{array}$ & $\begin{array}{l}-0.215 * \\
{[0.119]}\end{array}$ & $\begin{array}{l}-0.248 * * \\
{[0.122]}\end{array}$ \\
\hline-5 to 8 weeks & $\begin{array}{l}-0.236 \\
{[0.193]}\end{array}$ & $\begin{array}{l}-0.236 \\
{[0.197]}\end{array}$ & $\begin{array}{l}-0.125 \\
{[0.114]}\end{array}$ & $\begin{array}{l}-0.148 \\
{[0.109]}\end{array}$ \\
\hline - 9 to 12 weeks & $\begin{array}{l}0.187^{* * *} \\
{[0.052]}\end{array}$ & $\begin{array}{l}0.188 * * * \\
{[0.053]}\end{array}$ & $\begin{array}{l}0.231 * * \\
{[0.100]}\end{array}$ & $\begin{array}{l}0.230 * * \\
{[0.095]}\end{array}$ \\
\hline Long-run effect of Palestinian fatalities not in targeted killings & $\begin{array}{l}-0.841 \\
{[0.726]}\end{array}$ & $\begin{array}{l}-0.821 \\
{[0.736]}\end{array}$ & $\begin{array}{l}-0.436 \\
{[0.609]}\end{array}$ & $\begin{array}{l}-0.664 \\
{[0.613]}\end{array}$ \\
\hline \multicolumn{5}{|l|}{ Palestinian fatalities in targeted killlings prior to poll (100s) } \\
\hline-1 to 4 weeks & $\begin{array}{l}-0.012 \\
{[0.090]}\end{array}$ & & $\begin{array}{l}-0.274 \\
{[0.259]}\end{array}$ & \\
\hline-5 to 8 weeks & $\begin{array}{l}0.058 \\
{[0.114]}\end{array}$ & & $\begin{array}{l}-0.121 \\
{[0.252]}\end{array}$ & \\
\hline - 9 to 12 weeks & $\begin{array}{c}0.048 \\
{[0.272]}\end{array}$ & & $\begin{array}{l}-0.533 \\
{[0.488]}\end{array}$ & \\
\hline Long-run effect of Palestinian fatalities in targeted killings & $\begin{array}{l}0.373 \\
{[1.252]}\end{array}$ & & $\begin{array}{l}-3.708 \\
{[3.161]}\end{array}$ & \\
\hline \multicolumn{5}{|l|}{$\begin{array}{l}\text { Palestinian fatalities in targeted killings, } \\
\text { not object of targeted kllling, prior to poll (100s) }\end{array}$} \\
\hline-1 to 4 weeks & & $\begin{array}{c}0.126 \\
{[0.212]}\end{array}$ & & $\begin{array}{l}-0.969 * * * \\
{[0.377]}\end{array}$ \\
\hline-5 to 8 weeks & & $\begin{array}{l}-0.105 \\
{[0.297]}\end{array}$ & & $\begin{array}{l}1.365 \\
{[1.025]}\end{array}$ \\
\hline - 9 to 12 weeks & & $\begin{array}{c}0.001 \\
{[0.409]}\end{array}$ & & $\begin{array}{l}-0.103 \\
{[1.271]}\end{array}$ \\
\hline $\begin{array}{l}\text { Long-run effect of Palestinian fatalities in targeted killings, } \\
\text { not object of targeted killing }\end{array}$ & & $\begin{array}{l}0.091 \\
{[2.290]}\end{array}$ & & $\begin{array}{l}1.173 \\
{[8.171]}\end{array}$ \\
\hline \multicolumn{5}{|l|}{ Palestinian fatalities object of targeted killing prior to poll } \\
\hline-1 to 4 weeks & & $\begin{array}{l}-0.134 \\
{[0.178]}\end{array}$ & & $\begin{array}{l}0.283 \\
{[0.190]}\end{array}$ \\
\hline-5 to 8 weeks & & $\begin{array}{l}0.273 \\
{[0.485]}\end{array}$ & & $\begin{array}{l}-1.108 \\
{[0.732]}\end{array}$ \\
\hline - 9 to 12 weeks & & $\begin{array}{c}0.090 \\
{[0.542]}\end{array}$ & & $\begin{array}{l}-0.939 * \\
{[0.510]}\end{array}$ \\
\hline $\begin{array}{l}\text { Long-run effect of Palestinian fatalities object of targeted } \\
\text { killings }\end{array}$ & & $\begin{array}{l}0.915 \\
{[2.816]}\end{array}$ & & $\begin{array}{l}-7.056 \\
{[4.777]}\end{array}$ \\
\hline$N$ & 16,474 & 16,474 & 11,969 & 11,969 \\
\hline$R^{2}$ & 0.043 & 0.043 & 0.034 & 0.034 \\
\hline Number of poll $\times$ district clusters & 221 & 221 & 174 & 174 \\
\hline
\end{tabular}

Source: Authors' calculations using fatality data from B'Tselem, poll data from DSP, labor market data from the Palestinian Labor Force Survey and border closures data from the Palestinian Ministry of Labor.

Note: Estimated via OLS. Dependent variable is indicator for supporting Fatah or support for peace negotiations. All regressions include controls for overall number of Israeli fatalities, residence type, gender, age, marital status, refugee status, education dummies, local unemployment rate, the local wage rate, the number of closure days in the 30 days preceding the poll, period dummies, and 15 district fixed effects. Robust standard errors, adjusted for clustering at the poll-district level, in brackets; * indicates statistically significant at $10 \%$ level, ** indicates statistically significant at $5 \%$ level; *** indicates statistically significant at $1 \%$ level. 
Table 10

The Effect of Violence on Support for Fatah and Negotiations by Predicted Level of Radicalism

\begin{tabular}{|c|c|c|c|c|c|c|}
\hline & \multicolumn{3}{|c|}{ A. Support for Fatah } & \multicolumn{3}{|c|}{ B. Support for Peace Negotiations } \\
\hline & Non Radical & Radical & Difference & Non-radical & Radical & Difference \\
\hline \multicolumn{7}{|l|}{ Palestinian fatalities prior to poll (100s): } \\
\hline-1 to 4 weeks & $\begin{array}{l}-0.028 \\
{[0.117]}\end{array}$ & $\begin{array}{l}-0.253 * * * \\
{[0.090]}\end{array}$ & $\begin{array}{l}-0.225 * \\
{[0.127]}\end{array}$ & $\begin{array}{l}-0.078 \\
{[0.150]}\end{array}$ & $\begin{array}{l}-0.355 * * \\
{[0.159]}\end{array}$ & $\begin{array}{l}-0.278 \\
{[0.181]}\end{array}$ \\
\hline - 5 to 8 weeks & $\begin{array}{l}-0.136 \\
{[0.160]}\end{array}$ & $\begin{array}{l}-0.080 \\
{[0.135]}\end{array}$ & $\begin{array}{l}0.056 \\
{[0.170]}\end{array}$ & $\begin{array}{l}-0.157 \\
{[0.124]}\end{array}$ & $\begin{array}{l}-0.004 \\
{[0.142]}\end{array}$ & $\begin{array}{c}0.153 \\
{[0.150]}\end{array}$ \\
\hline - 9 to 12 weeks & $\begin{array}{l}0.178 * * * \\
{[0.074]}\end{array}$ & $\begin{array}{c}0.120 * \\
{[0.065]}\end{array}$ & $\begin{array}{l}-0.058 \\
{[0.098]}\end{array}$ & $\begin{array}{l}0.219 * * \\
{[0.106]}\end{array}$ & $\begin{array}{c}0.194 * \\
{[0.102]}\end{array}$ & $\begin{array}{l}-0.025 \\
{[0.109]}\end{array}$ \\
\hline Long-run effect of Palestinian fatalities & $\begin{array}{c}0.056 \\
{[0.743]}\end{array}$ & $\begin{array}{l}-0.852 \\
{[0.658]}\end{array}$ & $\begin{array}{l}-0.908 \\
{[0.807]}\end{array}$ & $\begin{array}{l}-0.063 \\
{[0.784]}\end{array}$ & $\begin{array}{l}-0.662 \\
{[0.873]}\end{array}$ & $\begin{array}{l}-0.599 \\
{[0.803]}\end{array}$ \\
\hline \multicolumn{7}{|l|}{ Local Israeli fatalities prior to poll (100s): } \\
\hline-1 to 4 weeks & $\begin{array}{l}-0.084 \\
{[0.198]}\end{array}$ & $\begin{array}{l}-0.037 \\
{[0.187]}\end{array}$ & $\begin{array}{l}0.047 \\
{[0.256]}\end{array}$ & $\begin{array}{l}-0.430 \\
{[0.311]}\end{array}$ & $\begin{array}{c}0.014 \\
{[0.279]}\end{array}$ & $\begin{array}{l}0.444 \\
{[0.317]}\end{array}$ \\
\hline - 5 to 8 weeks & $\begin{array}{l}0.208 \\
{[0.144]}\end{array}$ & $\begin{array}{l}0.153 \\
{[0.127]}\end{array}$ & $\begin{array}{l}-0.055 \\
{[0.152]}\end{array}$ & $\begin{array}{l}0.002 \\
{[0.159]}\end{array}$ & $\begin{array}{l}-0.134 \\
{[0.173]}\end{array}$ & $\begin{array}{l}-0.137 \\
{[0.177]}\end{array}$ \\
\hline - 9 to 12 weeks & $\begin{array}{l}-0.138 \\
{[0.187]}\end{array}$ & $\begin{array}{l}0.060 \\
{[0.248]}\end{array}$ & $\begin{array}{c}0.198 \\
{[0.286]}\end{array}$ & $\begin{array}{c}0.185 \\
{[0.265]}\end{array}$ & $\begin{array}{l}-0.062 \\
{[0.292]}\end{array}$ & $\begin{array}{l}-0.247 \\
{[0.278]}\end{array}$ \\
\hline Long-run effect of local Israeli fatalities & $\begin{array}{l}-0.060 \\
{[1.186]}\end{array}$ & $\begin{array}{c}0.703 \\
{[1.298]}\end{array}$ & $\begin{array}{c}0.763 \\
{[1.420]}\end{array}$ & $\begin{array}{l}-0.974 \\
{[1.949]}\end{array}$ & $\begin{array}{l}-0.732 \\
{[2.177]}\end{array}$ & $\begin{array}{c}0.241 \\
{[1.776]}\end{array}$ \\
\hline$N$ & & 16,474 & & & 11,969 & \\
\hline Number of poll $\times$ district clusters & & 221 & & & 174 & \\
\hline
\end{tabular}

Source: Authors' calculations using fatality data from B'Tselem, poll data from DSP, labor market data from the Palestinian Labor Force Survey and border closures data from the Palestinian Ministry of Labor.

Note: The coefficients in the table represent the means of estimated parameters from 200 bootstrap replications. The bootstrap procedu involved estimating first the probabilty of supporting Fatah on 25\% of the sample, calculating the "radical" dummy based on whether one's predicted probability of supporting Fatah fell below or above the median, and then estimating the main model on the remaining $75 \%$ of the sample. All regressions include controls for residence type, gender, age, marital status, refugee status, education dummies, two period dummies and 15 district fixed effects. * indicates statistically significant at $10 \%$ level, ** indicates statistically significant at $5 \%$ level; *** indicates statistically significant at $1 \%$ level. 
Table 11

The Effect of Violence on Support for Different Factions

\begin{tabular}{|c|c|c|c|c|c|c|}
\hline \multirow[b]{2}{*}{ Variable } & \multicolumn{6}{|c|}{ Multinomial logit: Marginal Effects on support for } \\
\hline & Fatah & Hamas & PFLP & PIJ/Islam. & Others & No One \\
\hline \multicolumn{7}{|l|}{ Palestinian fatalities prior to poll (100s): } \\
\hline-1 to 4 weeks & $\begin{array}{l}-0.179 * * \\
{[0.086]}\end{array}$ & $\begin{array}{l}-0.016 \\
{[0.086]}\end{array}$ & $\begin{array}{c}0.020 \\
{[0.020]}\end{array}$ & $\begin{array}{l}-0.009 \\
{[0.106]}\end{array}$ & $\begin{array}{c}0.004 \\
{[0.070]}\end{array}$ & $\begin{array}{c}0.180 \\
{[0.112]}\end{array}$ \\
\hline - 5 to 8 weeks & $\begin{array}{l}-0.115 \\
{[0.111]}\end{array}$ & $\begin{array}{l}-0.128 \\
{[0.095]}\end{array}$ & $\begin{array}{c}0.037 \\
{[0.030]}\end{array}$ & $\begin{array}{c}0.068 \\
{[0.093]}\end{array}$ & $\begin{array}{c}0.108 \\
{[0.104]}\end{array}$ & $\begin{array}{c}0.030 \\
{[0.093]}\end{array}$ \\
\hline - 9 to 12 weeks & $\begin{array}{l}0.170 * * * \\
{[0.048]}\end{array}$ & $\begin{array}{l}-0.018 \\
{[0.051]}\end{array}$ & $\begin{array}{l}-0.014 \\
{[0.015]}\end{array}$ & $\begin{array}{l}-0.100 \\
{[0.062]}\end{array}$ & $\begin{array}{l}0.065 * * \\
{[0.032]}\end{array}$ & $\begin{array}{l}-0.103 * \\
{[0.063]}\end{array}$ \\
\hline Long-run effect of Palestinian fatalities & $\begin{array}{l}-0.495 \\
{[0.534]}\end{array}$ & $\begin{array}{l}-0.647 \\
{[0.507]}\end{array}$ & $\begin{array}{c}0.170 \\
{[0.147]}\end{array}$ & $\begin{array}{l}-0.159 \\
{[0.550]}\end{array}$ & $\begin{array}{c}0.707 \\
{[0.463]}\end{array}$ & $\begin{array}{c}0.425 \\
{[0.633]}\end{array}$ \\
\hline $\begin{array}{l}\text { Local Israeli fatalities prior to poll (100 } \\
\text { - } 1 \text { to } 4 \text { weeks }\end{array}$ & $\begin{array}{l}-0.067 \\
{[0.132]}\end{array}$ & $\begin{array}{c}0.149 \\
{[0.243]}\end{array}$ & $\begin{array}{c}0.019 \\
{[0.055]}\end{array}$ & $\begin{array}{l}-0.310 * * * \\
{[0.115]}\end{array}$ & $\begin{array}{c}0.128 \\
{[0.109]}\end{array}$ & $\begin{array}{c}0.080 \\
{[0.237]}\end{array}$ \\
\hline - 5 to 8 weeks & $\begin{array}{l}0.186 * \\
{[0.107]}\end{array}$ & $\begin{array}{l}-0.195 \\
{[0.142]}\end{array}$ & $\begin{array}{c}0.040 \\
{[0.035]}\end{array}$ & $\begin{array}{l}-0.059 \\
{[0.103]}\end{array}$ & $\begin{array}{l}-0.035 \\
{[0.072]}\end{array}$ & $\begin{array}{c}0.063 \\
{[0.177]}\end{array}$ \\
\hline - 9 to 12 weeks & $\begin{array}{l}-0.058 \\
{[0.168]}\end{array}$ & $\begin{array}{c}0.086 \\
{[0.167]}\end{array}$ & $\begin{array}{c}0.049 \\
{[0.047]}\end{array}$ & $\begin{array}{l}0.304 * * * \\
{[0.103]}\end{array}$ & $\begin{array}{l}-0.135 \\
{[0.087]}\end{array}$ & $\begin{array}{l}-0.245 * \\
{[0.146]}\end{array}$ \\
\hline Long-run effect of Israeli fatalities & $\begin{array}{l}0.242 \\
{[0.976]}\end{array}$ & $\begin{array}{l}0.157 \\
{[1.300]}\end{array}$ & $\begin{array}{l}0.434 \\
{[0.333]}\end{array}$ & $\begin{array}{l}-0.259 \\
{[0.788]}\end{array}$ & $\begin{array}{l}-0.165 \\
{[0.632]}\end{array}$ & $\begin{array}{l}-0.409 \\
{[1.299]}\end{array}$ \\
\hline $\begin{array}{l}N \\
\text { Number of poll } \times \text { district clusters }\end{array}$ & \multicolumn{6}{|c|}{16,474} \\
\hline
\end{tabular}

Source: Authors' calculations using fatality data from B'Tselem, poll data from DSP, labor market data from the Palestinian Labor Force Survey and border closures data from the Palestinian Ministry of Labor.

Note: Entries in table are marginal effects. All regressions include controls for residence type, gender, age, marital status, refugee status, education dummies, local unemployment rate, the local wage rate, the average number of closure days in the 30 days preceding the poll, and two period dummies. The models include 15 district fixed effects. Robust standard errors, adjusted for clustering at the poll-district level, in brackets; * indicates statistically significant at 10\% level, ** indicates statistically significant at 5\% level; *** indicates statistically significant at $1 \%$ level. 
Table 12

The Effect of Israeli Fatalities Claimed by Different Factions on Support for Fatah

\begin{tabular}{|c|c|c|c|c|c|c|}
\hline \multirow[b]{2}{*}{ Varible } & \multicolumn{6}{|c|}{ Multinomial Logit: Marginal Effects for } \\
\hline & Fatah & Hamas & PFLP & PIJ/ Islamic & Others & No one \\
\hline $\begin{array}{l}\text { Palestinian fatalities prior to poll (100s): } \\
\quad-1 \text { to } 4 \text { weeks }\end{array}$ & $\begin{array}{l}-0.194 * * \\
{[0.094]}\end{array}$ & $\begin{array}{c}0.039 \\
{[0.095]}\end{array}$ & $\begin{array}{c}0.029 \\
{[0.021]}\end{array}$ & $\begin{array}{c}-0.002 \\
{[0.118]}\end{array}$ & $\begin{array}{r}0.004 \\
{[0.072]}\end{array}$ & $\begin{array}{l}0.124 \\
{[0.084]}\end{array}$ \\
\hline - 5 to 8 weeks & $\begin{array}{l}-0.080 \\
{[0.106]}\end{array}$ & $\begin{array}{l}-0.155 \\
{[0.094]}\end{array}$ & $\begin{array}{c}0.033 \\
{[0.031]}\end{array}$ & $\begin{array}{r}0.033 \\
{[0.097]}\end{array}$ & $\begin{array}{c}0.120 \\
{[0.092]}\end{array}$ & $\begin{array}{l}0.048 \\
{[0.096]}\end{array}$ \\
\hline - 9 to 12 weeks & $\begin{array}{l}0.169 * * * \\
{[0.047]}\end{array}$ & $\begin{array}{l}-0.028 \\
{[0.050]}\end{array}$ & $\begin{array}{l}-0.008 \\
{[0.011]}\end{array}$ & $\begin{array}{c}-0.087 \\
{[0.061]}\end{array}$ & $\begin{array}{c}0.049 \\
{[0.034]}\end{array}$ & $\begin{array}{l}-0.094 \\
{[0.061]}\end{array}$ \\
\hline Long-run effect of Palestinian fatalities & $\begin{array}{l}-0.424 \\
{[0.519]}\end{array}$ & $\begin{array}{l}-0.575 \\
{[0.525]}\end{array}$ & $\begin{array}{c}0.219 \\
{[0.146]}\end{array}$ & $\begin{array}{l}-0.222 \\
{[0.580]}\end{array}$ & $\begin{array}{c}0.688 \\
{[0.446]}\end{array}$ & $\begin{array}{l}0.313 \\
{[0.542]}\end{array}$ \\
\hline $\begin{array}{l}\text { Israeli fatalities claimed by Fatah prior to poll, local (10 } \\
-1 \text { to } 4 \text { weeks }\end{array}$ & $\begin{array}{l}-0.096 \\
{[0.529]}\end{array}$ & $\begin{array}{c}0.478 \\
{[0.477]}\end{array}$ & $\begin{array}{c}0.166 * \\
{[0.101]}\end{array}$ & $\begin{array}{r}0.125 \\
{[0.450]}\end{array}$ & $\begin{array}{c}0.082 \\
{[0.226]}\end{array}$ & $\begin{array}{l}-0.756 \\
{[0.575]}\end{array}$ \\
\hline - 5 to 8 weeks & $\begin{array}{c}0.025 \\
{[0.225]}\end{array}$ & $\begin{array}{c}0.324 \\
{[0.255]}\end{array}$ & $\begin{array}{c}-0.078 \\
{[0.083]}\end{array}$ & $\begin{array}{r}0.086 \\
{[0.191]}\end{array}$ & $\begin{array}{l}-0.376 \\
{[0.300]}\end{array}$ & $\begin{array}{l}0.019 \\
{[0.188]}\end{array}$ \\
\hline - 9 to 12 weeks & $\begin{array}{c}0.339 \\
{[0.250]}\end{array}$ & $\begin{array}{l}-0.440 \\
{[0.280]}\end{array}$ & $\begin{array}{l}-0.191 * \\
{[0.111]}\end{array}$ & $\begin{array}{r}0.308 \\
{[0.263]}\end{array}$ & $\begin{array}{r}0.035 \\
{[0.222]}\end{array}$ & $\begin{array}{l}-0.050 \\
{[0.261]}\end{array}$ \\
\hline Long-run effect of Israeli Fatalities claimed by Fatah & $\begin{array}{c}1.070 \\
{[2.712]}\end{array}$ & $\begin{array}{c}1.446 \\
{[2.609]}\end{array}$ & $\begin{array}{l}-0.411 \\
{[0.725]}\end{array}$ & $\begin{array}{c}2.077 \\
{[2.326]}\end{array}$ & $\begin{array}{l}-1.033 \\
{[1.727]}\end{array}$ & $\begin{array}{l}-3.149 \\
{[2.775]}\end{array}$ \\
\hline $\begin{array}{l}\text { Israeli fatalities claimed by Hamas prior to poll (100s) } \\
-1 \text { to } 4 \text { weeks }\end{array}$ & $\begin{array}{l}-0.070 \\
{[0.172]}\end{array}$ & $\begin{array}{l}0.427 * * * \\
{[0.166]}\end{array}$ & $\begin{array}{c}0.047 \\
{[0.042]}\end{array}$ & $\begin{array}{l}-0.281 * * \\
{[0.134]}\end{array}$ & $\begin{array}{r}0.134 \\
{[0.172]}\end{array}$ & $\begin{array}{l}-0.256 \\
{[0.191]}\end{array}$ \\
\hline - 5 to 8 weeks & $\begin{array}{l}0.458 * * * \\
{[0.181]}\end{array}$ & $\begin{array}{l}-0.228 * \\
{[0.132]}\end{array}$ & $\begin{array}{l}0.096 * * * \\
{[0.037]}\end{array}$ & $\begin{array}{l}-0.220 * * * \\
{[0.071]}\end{array}$ & $\begin{array}{c}-0.053 \\
{[0.107]}\end{array}$ & $\begin{array}{l}-0.053 \\
{[0.298]}\end{array}$ \\
\hline - 9 to 12 weeks & $\begin{array}{l}-0.210 \\
{[0.292]}\end{array}$ & $\begin{array}{c}0.354 \\
{[0.247]}\end{array}$ & $\begin{array}{c}0.010 \\
{[0.052]}\end{array}$ & $\begin{array}{r}0.202 \\
{[0.199]}\end{array}$ & $\begin{array}{l}-0.178 * \\
{[0.096]}\end{array}$ & $\begin{array}{l}-0.178 \\
{[0.195]}\end{array}$ \\
\hline Long-run effect of Israeli fatalities claimed by Hamas & $\begin{array}{c}0.710 \\
{[1.619]}\end{array}$ & $\begin{array}{c}2.212 * \\
{[1.327]}\end{array}$ & $\begin{array}{c}0.610 \\
{[0.319]}\end{array}$ * & $\begin{array}{l}-1.194 \\
{[1.049]}\end{array}$ & $\begin{array}{l}-0.391 \\
{[0.922]}\end{array}$ & $\begin{array}{l}-1.947 \\
{[1.692]}\end{array}$ \\
\hline $\begin{array}{l}\text { Israeli fatalities claimed by PIJ prior to poll (100s) } \\
-1 \text { to } 4 \text { weeks }\end{array}$ & $\begin{array}{l}0.274 * * \\
{[0.125]}\end{array}$ & $\begin{array}{l}-0.494 * * * \\
{[0.167]}\end{array}$ & $\begin{array}{l}-0.216 * \\
{[0.121]}\end{array}$ & $\begin{array}{l}-0.479 * * * \\
{[0.141]}\end{array}$ & $\begin{array}{c}0.057 \\
{[0.076]}\end{array}$ & $\begin{array}{l}0.858 * * * \\
{[0.169]}\end{array}$ \\
\hline - 5 to 8 weeks & $\begin{array}{l}-0.104 \\
{[0.350]}\end{array}$ & $\begin{array}{l}-0.477 \\
{[0.643]}\end{array}$ & $\begin{array}{l}0.148 * * * \\
{[0.052]}\end{array}$ & $\begin{array}{l}-0.451 * \\
{[0.272]}\end{array}$ & $\begin{array}{l}-0.552 * \\
{[0.285]}\end{array}$ & $\begin{array}{l}1.436 * * * \\
{[0.260]}\end{array}$ \\
\hline - 9 to 12 weeks & $\begin{array}{l}-0.222 \\
{[0.396]}\end{array}$ & $\begin{array}{l}-0.234 \\
{[0.153]}\end{array}$ & $\begin{array}{l}0.104 * * * \\
{[0.038]}\end{array}$ & $\begin{array}{c}0.275 * \\
{[0.153]}\end{array}$ & $\begin{array}{l}-0.058 \\
{[0.146]}\end{array}$ & $\begin{array}{l}0.135 \\
{[0.448]}\end{array}$ \\
\hline Long-run effect of Israeli Fatalities claimed by PIJ & $\begin{array}{l}-0.208 \\
{[2.745]}\end{array}$ & $\begin{array}{l}-4.818 * \\
{[2.975]}\end{array}$ & $\begin{array}{c}0.144 \\
{[0.621]}\end{array}$ & $\begin{array}{l}-2.622 \\
{[1.848]}\end{array}$ & $\begin{array}{l}-2.214 \\
{[1.430]}\end{array}$ & $\begin{array}{l}9.717 * * * \\
{[2.383]}\end{array}$ \\
\hline $\begin{array}{l}\text { Israeli fatalities claimed by others prior to poll (100s) } \\
-1 \text { to } 4 \text { weeks }\end{array}$ & $\begin{array}{l}-0.462 \\
{[2.362]}\end{array}$ & $\begin{array}{l}-8.436 * * * \\
{[2.797]}\end{array}$ & $\begin{array}{c}0.941 \\
{[0.921]}\end{array}$ & $\begin{array}{r}3.239 \\
{[2.066]}\end{array}$ & $\begin{array}{c}6.557 * \\
{[3.432]}\end{array}$ & $\begin{array}{l}-1.839 \\
{[1.476]}\end{array}$ \\
\hline - 5 to 8 weeks & $\begin{array}{l}-1.939 * * * \\
{[0.798]}\end{array}$ & $\begin{array}{c}1.373 * \\
{[0.833]}\end{array}$ & $\begin{array}{l}-0.310 * \\
{[0.180]}\end{array}$ & $\begin{array}{r}0.648 \\
{[0.451]}\end{array}$ & $\begin{array}{c}0.338 \\
{[0.497]}\end{array}$ & $\begin{array}{l}-0.110 \\
{[1.049]}\end{array}$ \\
\hline - 9 to 12 weeks & $\begin{array}{c}1.143 \\
{[2.018]}\end{array}$ & $\begin{array}{l}5.480 * * \\
{[2.412]}\end{array}$ & $\begin{array}{r}1.398 \\
{[0.875]}\end{array}$ & $\begin{array}{l}-5.675 * \\
{[3.004]}\end{array}$ & $\begin{array}{l}4.457 \text { *** } \\
{[1.302]}\end{array}$ & $\begin{array}{c}-6.803 * * \\
{[3.192]}\end{array}$ \\
\hline Long-run effect of Israeli fatalities claimed by others & $\begin{array}{l}-5.030 \\
{[14.226]}\end{array}$ & $\begin{array}{l}-6.333 \\
{[15.106]}\end{array}$ & $\begin{array}{c}8.114 \\
{[5.181]}\end{array}$ & $\begin{array}{c}-7.152 \\
{[15.054]}\end{array}$ & $\begin{array}{l}45.408 * * * \\
{[14.944]}\end{array}$ & $\begin{array}{c}-35.008 * * \\
{[16.715]}\end{array}$ \\
\hline $\begin{array}{l}N \\
\text { Number of poll } \times \text { district clusters }\end{array}$ & & & & $\begin{array}{l}474 \\
21\end{array}$ & & \\
\hline
\end{tabular}

Source: Authors' calculations using fatality data from B'Tselem, poll data from DSP, labor market data from the Palestinian Labor Force Survey and border closures data from the Palestinian Ministry of Labor.

Note: Entries in the table represent marginal effects. All regressions include controls for area, residence type, gender, age, marital status, refugee status, religion, education dummies, local unemployment rate, the local wage rate, the average number of closure days in the 30 days preceding the poll, and period controls. Robust standard errors, adjusted for clustering at the poll-district level, in brackets; * indicates statistically significant at $10 \%$ level, ** indicates statistically significant at $5 \%$ level; *** indicates statistically significant at $1 \%$ level. 
Appendix Table 1

Probability of Supporting Fatah Based on Pooled Cross-Sectional Demographic and Economic Characteristics

\begin{tabular}{|c|c|c|}
\hline Variable & Males & Females \\
\hline \multicolumn{3}{|l|}{ Type of residence } \\
\hline City & $\begin{array}{l}-0.010 \\
{[0.038]}\end{array}$ & $\begin{array}{l}-0.077 * \\
{[0.041]}\end{array}$ \\
\hline Refugee Camp & $\begin{array}{c}0.031 \\
{[0.061]}\end{array}$ & $\begin{array}{l}-0.047 \\
{[0.058]}\end{array}$ \\
\hline Refugee & $\begin{array}{c}0.040 \\
{[0.034]}\end{array}$ & $\begin{array}{c}0.078 * \\
{[0.042]}\end{array}$ \\
\hline Married & $\begin{array}{l}0.115 * * * \\
{[0.042]}\end{array}$ & $\begin{array}{l}-0.018 \\
{[0.045]}\end{array}$ \\
\hline Age & $\begin{array}{l}-0.007 * * * \\
{[0.001]}\end{array}$ & $\begin{array}{c}0.000 \\
{[0.001]}\end{array}$ \\
\hline \multicolumn{3}{|l|}{ Education } \\
\hline Elementary School & $\begin{array}{c}0.105 * \\
{[0.060]}\end{array}$ & $\begin{array}{c}0.079 \\
{[0.054]}\end{array}$ \\
\hline Middle School & $\begin{array}{l}-0.045 \\
{[0.063]}\end{array}$ & $\begin{array}{c}0.024 \\
{[0.056]}\end{array}$ \\
\hline Secondary Education & $\begin{array}{c}0.080 \\
{[0.064]}\end{array}$ & $\begin{array}{c}0.028 \\
{[0.057]}\end{array}$ \\
\hline Some College & $\begin{array}{c}0.042 \\
{[0.072]}\end{array}$ & $\begin{array}{c}0.110 \\
{[0.075]}\end{array}$ \\
\hline College Degree & $\begin{array}{c}0.036 \\
{[0.068]}\end{array}$ & $\begin{array}{c}0.007 \\
{[0.080]}\end{array}$ \\
\hline$N$ & 8,111 & 8,363 \\
\hline$R^{2}$ & 0.011 & 0.011 \\
\hline Number of poll $\times$ district clusters & 221 & 221 \\
\hline
\end{tabular}

Source: Authors' calculations using fatality data from B'Tselem, poll data from DSP, labor market data from the Palestinian Labor Force Survey and border closures data from the Palestinian Ministry of Labor

Note: Estimated via Probit. Dependent variable is indicator for supporting Fatah. Both columns include 15 district fixed effects. Robust standard errors, adjusted for clustering at the poll-district level, in brackets; * indicates statistically significant at $10 \%$ level, ** indicates statistically significant at $5 \%$ level; *** indicates statistically significant at $1 \%$ level. 